\title{
RELACIONES SOCIALES Y ETNICIDAD EN EL ESPACIO AYMARA CHILENO'
}

\author{
SOCIAL RELATIONS AND ETHNICITY IN CHILEAN AYMARA SPACE
}

\author{
Hans Gundermann ${ }^{1}$, Héctor González ${ }^{2}$ y John Durston ${ }^{3}$
}

\begin{abstract}
Presentamos en este trabajo un estudio de las relaciones interétnicas, entendidas como tipos específicos de relación social en que los sujetos interactuantes participan de inscripciones sociales y posicionamientos de etnicidad. Privilegiamos en el análisis a los actores sociales, su subjetividad y las prácticas que despliegan en los espacios de vinculación interétnica. Todo ello en sistemas sociales en que se estructuran las relaciones de interetnicidad y tienen lugar procesos históricos de conformación y cambio de esos vínculos. El caso aymara chileno analizado corresponde a una realidad de conformación reciente de relaciones interétnicas, sobre la base de un sistema de alteridades e identificaciones previas en que convergen una historia colonial y la construcción moderna de ciudadanía. El surgimiento étnico aymara, como el de los demás pueblos originarios andinos, guarda una relación estrecha con la política de acción afirmativa iniciada por las agencias públicas a inicio de la década de 1990, en la medida en que crea un nexo recursivo entre agentes indígenas que se etnifican y agencias públicas que construyen la política en relación con agentes etnificados. Ello permite explicar que allí donde con mayor frecuencia las interacciones se etnifican es, precisamente, cuando se dan entre integrantes de los organismos públicos y personas, grupos y organizaciones que participan de identificaciones como pueblo originario. En otros ámbitos sociales y con otros sujetos, especialmente en espacios urbanos, el carácter interétnico de las relaciones es menos frecuente, irregular, contingente $\mathrm{u}$ opcional.
\end{abstract}

Palabras claves: relaciones interétnicas, aymaras chilenos, ámbitos de interacción, prejuicios étnicos.

This study deals with interethnic relations, understood as specific types of social relationships, in which the interacting subjects maintain social positions of ethnicity. The authors concentrate their analysis on social actors, their subjectivity and the practices they bring into play in spaces of interethnic encounters. These interethnic relations are structured by social systems and by historical processes that form and transform them. The case of Chilean Aymara analyzed here corresponds to a reality of recently constituted interethnic relations, with the convergence of colonial history and the modern construction of citizenship. The surge of Aymaran ethnicity, as is also the case with the other Andean first peoples, is closely related to the policy of affirmative action started in the early 1990's by Chilean government agencies. This policy created a recursive link between indigenous actors, who became ethnified, and public agencies, which built policy in relation to these ethnified actors. This explains why the greatest frequency of interethnic relations occur precisely where public officials interact with persons, groups and organizations that self-identify as belonging to first nations. In other social contexts and with other subjects, especially in urban spaces, relations have less interethnic content, and this tends to be less frequent, irregular, contingent or optional.

Key words: Interethnic relations, Chilean Aymaras, spheres of interaction, ethnic prejudices.

Acción colectiva y movilizaciones indígenas en defensa de sus tierras y recursos son antiguas en el Chile posterior a la anexión del extremo norte del territorio, de la isla de Pascua y de la ocupación de La Araucanía, ocurridas en la década de 1880. Las demandas en áreas indígenas por desarrollo, inversión en infraestructura, defensa ante usurpaciones o amenazas de particulares $\mathrm{u}$ otros grupos también son una constante de la historia moderna de los pueblos originarios $^{2}$. Existe también alguna continuidad en las modalidades de respuesta institucional desde el Estado ante las demandas indígenas (Vergara et al. 2005). Resulta nueva a nuestro entender la codificación, reelaboración y expansión en términos étnicos y de pueblo indígena que mucha de esta organización, acción y demandas tiene durante las últimas décadas. De allí que convenga llamar a estos fenómenos como surgimiento o construcción más que una simple continuidad o re-resurgimiento (también Bengoa 2000). Esto es especialmente

1 Instituto de Investigaciones Arqueológicas y Museo (IIAM), Universidad Católica del Norte, San Pedro de Atacama, Chile. Calle Gustavo Le Paige N 380, San Pedro de Atacama, Chile. hgunder@ucn.cl

2 Departamento de Antropología, Facultad de Ciencias Sociales y Jurídicas, Universidad de Tarapacá, Arica, Chile. hgonzale@uta.cl

3 Programa de las Naciones Unidas para el Desarrollo (PNUD), Santiago, Chile. 1johndurston@gmail.com 
cierto en el caso de los pueblos andinos, los que a la sazón no tenían una conciencia étnica definida como tal y esta es claramente posterior y en directa relación con la política indígena inaugurada en 1990 por los Gobiernos de la Concertación de Partidos por la Democracia. Y tampoco, en consecuencia, acción colectiva y demandas que apelaran a esa totalidad étnica. Por el contrario, aquellas fueron principalmente desarrollistas, ciudadanas y sujetas a marcos locales (Gundermann 2000, 2003; Comisión de Verdad Histórica y Nuevo Trato con los Pueblos Indígenas 2008) ${ }^{3}$.

Con la promulgación de la Ley Indígena $\mathrm{N}^{\mathrm{o}} 19.253$ de 1993 se inaugura una política indígena étnica, en convergencia con las ideas que sobre multiculturalidad, etnodesarrollo y autonomía venían ganando espacio en la agenda de los movimientos indígenas en Latinoamérica y Chile ${ }^{4}$. La política indígena y sus agencias tratan en lo sucesivo con entidades sociales definidas por su especificidad histórica, social y cultural (pueblos originarios o, más genéricamente, etnias), diferenciándose de un pasado en que se abordaban como grupos agrarios o cuya vulnerabilidad y postración los ponía en clara desventaja ante el resto de la sociedad (y, por tanto, como grupos marginales o en estado de pobreza). Pero se trata de algo más que el simple reconocer lo que no se había reconocido ni otorgado estatus político. La relación es más compleja: las agencias del Estado participan de la formación de actores étnicos, desechando o pasando a un segundo plano otras inscripciones de sujeto ${ }^{5}$, como campesino, poblador indígena o habitante rural pobre y marginal, en una relación recursiva no carente de tensiones y conflicto, pero también progresiva, con organizaciones, intelectuales y dirigentes indígenas que se conforman como interlocutores reconocidos y legitimados por la política étnica. Ellos mismos, por sí y en interlocución con el Estado, van desarrollando el lenguaje de la etnicidad ${ }^{6}$ adecuado a sus circunstancias, premunidos de lo cual van redefiniendo su propia condición de sujetos (étnicos) y formulando los términos (etnificados) de la relación con las agencias estatales y sus funcionarios ${ }^{7}$. Esta formación discursiva puede plantearse más o menos cercana con el multiculturalismo estatal; en algunas de sus variantes puede incluso formularse en directa contraposición con aquel.

Pero el Estado es muchísimo más amplio que algunos organismos sectoriales o programas especiales y los indígenas se relacionan activamente con un abanico de instituciones. Asimismo, estos participan activamente de las economías y las sociedades regionales de las que forman parte. Contingentes mayoritarios de personas integrantes de pueblos indígenas del país han emigrado a otras zonas (como la Región Metropolitana) o lo hacen estacionalmente (siguiendo el ciclo de la fruticultura de exportación, por ejemplo). Remitiéndonos a los pueblos originarios de la región andina, altos porcentajes de población aymara, quechua, atacameña o coya son residentes urbanos. A su vez, los espacios indígenas históricos viven una progresiva mayor presencia y residencia de no indígenas. Representaciones colectivas generales referidas a los pueblos originarios bajo categorías como las de "indio" 8 han estado vigentes en la sociedad y están siendo reelaboradas en los tiempos presentes bajo el influjo de los nuevos aires étnicos. La existencia de "grupos étnicos", "culturas originarias", "pueblo mapuche" o "pueblo aymara" ha sido paulatinamente divulgada por las instituciones educativas y los medios de difusión públicas. Son hoy de dominio público en el país y, en cuanto a sus efectos prácticos, muchas personas tienen una idea definida de a qué se refieren esos términos.

Si lo anterior constituye una transformación importante en el campo de las relaciones entre la sociedad, el Estado y los pueblos indígenas, podemos interrogarnos: ¿con qué extensión y profundidad las relaciones sociales de indígenas con no indígenas y recíprocamente están dándose a través de estipulaciones de etnicidad?; o bien, ¿ocurren bajo esquemas heredados en que se hacen presentes categorías de alteridad no étnicas como las de clase, una sociocultural tan específicamente latinoamericana como la de "indio", y/o étnicas como la de "mapuche"?; ¿o quizá se han etnificado en el marco de lo establecido por las categorías impuestas por la legislación, las políticas públicas y la penetración de nuevas representaciones en la sociedad? Llegado el caso, ¿lo étnico es un rasgo privativo de las relaciones entre indígenas y agencias públicas, o lo es también de algún sistema histórico de relaciones regionales, o se ha generalizado?; y si se ha extendido ¿cuáles son sus alcances y características en las interacciones y prácticas sociales? y ¿qué cambios de índole cultural, social o política están o no induciendo estas nuevas inscripciones de sujeto colectivo. El surgimiento de lo étnico aymara puede ayudarnos a formular respuestas tentativas acerca de estas interrogantes. 


\section{Las Relaciones Interétnicas Aymaras}

El conocimiento de las relaciones entre personas y grupos en las que se hacen presentes estipulaciones de identidad/alteridad étnica supone considerar los actores sociales, su subjetividad y sus prácticas. Las relaciones interétnicas son entonces tipos de relaciones entre actores que actúan en tanto que sujetos étnicos. Las relaciones directas o indirectas entre personas y grupos en que se hace presente la etnicidad dependen de contextos sociales e históricos que las encuadran, proveyendo oportunidades e imponiendo límites a la realización de tales relaciones. Una acción social es toda acción que sea significativa, con sentido para quienes la realizan, influyendo la conducta de otros y orientándose la acción indicada por dicha influencia ${ }^{10}$. En las relaciones interétnicas pueden estar presentes una u otra forma de acción o una combinación de ellas y no solo, por parte de los indígenas, una de tipo tradicional como a veces suele implicarse. Las interacciones se vuelven relaciones en forma progresiva, a partir de su repetición y la formación de vínculos entre actores. Formas de acción y relaciones sociales características suelen dar origen a prácticas sociales o "modos de actuar y de relacionarse que las personas despliegan en espacios concretos de acción" (PNUD 2009). Los patrones de interacción y las prácticas reproducen la asimetría de poder que suele existir en las sociedades en que la interetnicidad es un fenómeno presente y relevante. No obstante, los grupos subordinados tienen siempre cierto poder de transformación de las relaciones sociales, siendo frecuente que se gesten precisamente en la demanda por alterar relaciones de poder desfavorables entre diversos grupos étnicos y que estructuran dinámicas de desigualdad de larga data (Comaroff y Comaroff 1992:49-67).

El elemento definitorio de las relaciones interétnicas o de interetnicidad es el sentido de pertenencia, adscripción y participación en un pueblo indígena, de personas y grupos en relación con otros que mantienen y hacen relevantes otros sentidos de pertenencia colectiva, étnicos o no ${ }^{11}$. Las personas incorporan varias identificaciones colectivas, las que se originan en roles asociados al género, generación, linaje, posición institucional y de empleo, condición socioeconómica, residencia, ubicación de clase, construcción biográfica, etc., y también desde otros actuados por voluntad propia. En particular, la identificación y sentido de pertenencia a una identidad étnica es el resultado de la acción de las personas, del grupo al cual se dirige esa pertenencia y por los otros colectivos. La identidad no es, entonces, exactamente relativa a la mayor o menor proximidad que una persona tenga con un núcleo cultural dado (para el caso indígena nacional, uno rural con instituciones caracterizadoras), sino que a contenidos ideológicos y fenómenos de identificación. Por ejemplo, para la mayoría de los más conspicuos dirigentes étnicos no puede dudarse acerca de su identidad como identificación y postulado de pertenencia, pero otra cosa es su compenetración con lo cultural tradicional. De este modo, los límites o fronteras de las identidades étnicas se relacionan con contenidos ideológicos e identificación subjetiva y voluntaria, independientemente del manejo que tienen las personas de los códigos culturales tradicionales de un pueblo ${ }^{12}$.

De esta manera, hablar de relaciones interétnicas aymaras supone que la población aymara se relaciona extensivamente con no aymaras en espacios sociales identificables. Y luego, que estén presentes sujetos sociales que se identifiquen como aymaras y conciban la colectividad a la que estipulan pertenecer como una etnia, pueblo o nación. Si lo primero es algo que se ha realizado intensa, aunque progresivamente, en la historia indígena moderna del norte de Chile, lo segundo es un asunto bastante más reciente. En rigor, arranca en los últimos veinticinco años, con una fuerte inflexión de crecimiento durante la segunda mitad de la década de 1990. De esta manera, si hay personas que se consideran a sí mismas como aymaras y otras como no aymaras y en la interacción actúan como sujetos étnicos, o considerándose tales, entonces el carácter interétnico de la relación podría evaluarse afirmativamente. Subrayamos lo de interétnico y no lo intercultural porque esto último lleva implícita la premisa de que en las interacciones se hace intervenir, al menos por una de las partes, lo cultural propiamente indígena (pautas, patrones o modelos de comportamiento y significación específicamente aymaras, en este caso), lo que en muchos casos está lejos de ocurrir así debido a la variedad de repertorios culturales ${ }^{13}$ que los sujetos sociales contemporáneos, los indígenas incluidos, ponen en ejercicio en las relaciones sociales. Asimismo, interacciones entre sujetos en que las identificaciones, sentidos de pertenencia y percepciones de alteridad y fronteras sociales adoptan una perspectiva étnica son nuevas en el espacio aymara $^{14}$. Esto es, interacciones o relaciones en las que se hacen presente identificación, en algún 
grado, y pertenencia, en sus distintas posibilidades, a una entidad genérica nominada como pueblo originario aymara.

\subsection{Identidad, identificación y alteridad étnica en la historia moderna aymara}

Estuvieron históricamente presentes inscripciones y delimitaciones sociales en grupos radicados en espacios regionales que hoy no dudamos en calificar como aymaras, pero que se organizaban bajo la noción genérica de "indio". Como sabemos, se trata esta última de una categoría de clasificación fiscal, política y social establecida con el régimen colonial impuesto por la Corona de España. Aquel consideraba una estructura de dos repúblicas: la de los "españoles, con sus fueros y privilegios", y la de los indios, con menos derechos y protección e importantes obligaciones. Esta categoría de inscripción, ahora en una versión neocolonial, se prolongó en los países surgidos de la disolución del virreinato del Perú, con más o menos duración durante el siglo XIX, según si los tributos (con el nombre de "contribución indigenal") fueron todavía necesarios para el financiamiento del Estado. Con la anexión de los territorios meridionales de Perú y Bolivia a Chile desde 1879, año de inicio de la guerra del Pacífico, culmina cualquier relación de tipo neocolonial entre las comunidades de indios y el Estado. En lo sucesivo, rigen lazos jurídicos y políticos modernos. Los residentes de las zonas interiores andinas de estas nuevas regiones serán ciudadanos chilenos o residentes extranjeros, si así lo eligieron, sujetos a las normas y leyes del país beneficiario de la anexión territorial. Otra cosa es, por cierto, la posibilidad de ejercer efectivamente esos derechos ciudadanos. Esta última es una cuestión que se ha dado lentamente en el país durante el siglo XX, no sin estancamientos e incluso retrocesos. Con mayor razón deben suponerse rezagos en áreas geográfica y poblacionalmente marginales (Gundermann 2003) ${ }^{15}$.

Durante el primer medio siglo de dominio chileno sobre la zona fue una preocupación de las autoridades que prevaleciera la población nacional: en la de Arica y Tacna, por el acuerdo con Perú de definir su soberanía mediante un plebiscito (que por lo demás nunca se realizó; esto se resolvió finalmente en 1929 con el arreglo de Arica para Chile y la devolución de Tacna a Perú); en la de Tarapacá, por la numerosa población peruana residente en una provincia estratégica para la economía del país. Se hizo así importante determinar la composición de la población residente y cada quien se vio obligado a adherir a una nacionalidad. Las tensiones entre Perú y Chile polarizaron las adscripciones nacionales de "peruano" y "chileno" (también las de "boliviano" y otras nacionalidades se hacen plenamente visibles). Ello afecta las zonas interiores, en particular los poblados y comunidades de la precordillera andina que en ese entonces se autodefinieron mayoritariamente como peruanos. Las comunidades de la alta cordillera andina, pocas en número, con menor población y mayoritariamente monolingües del aymara, participaron menos de este proceso de construcción de una identidad nacional peruana.

Una transformación político ideológica de gran alcance tiene lugar, entonces, en las comunidades antiguamente de indios de Tarapacá y Arica. Se pasa en forma progresiva de la condición de indio a la de ciudadano con una definida identidad nacional. En lo sucesivo, los residentes andinos fueron cada vez más frecuentemente considerados como ciudadanos, de nacionalidad peruana o chilena (entre estos últimos, los hijos de padres peruanos que nacían en el territorio anexado por Chile). Ya adentrándose el siglo XX, ellos mismos hicieron prevalecer en sus adscripciones de identidad a la nacional, oficial, positiva y prestigiosa, más inclusiva y funcional. En particular cuando, por efecto de los avances en la castellanización, mejoras económicas y educacionales, mayor apertura en las experiencias de vida, aquellos signos culturales característicos en el reconocimiento de la condición indígena (lengua, vestuario) fueron menos manifiestos. Como puede suponerse, la preeminencia de lo nacional en la subjetividad y los discursos sociales se concentró en los valles bajos y precordillera andina, más directamente integradas a la economía y los centros urbanos regionales. En todo este devenir la idea de indio y su presencia en las relaciones sociales no desapareció, aunque su permanencia se realizó a costa de una significativa transformación semántica.

Hacia la segunda mitad del siglo XIX empieza a hacerse presente un nuevo significado para la noción de indio, quedando atrás paulatinamente el que fue característico como categoría tributaria, estamento o grupo social subordinado sujeto a obligaciones fiscales especiales (así como a derechos sobre la tierra y protección ante presiones y exacciones de terceros). Por diferencia con el caso mapuche, una acepción de indio como "raza" no se generalizó entre 
la población originaria andina regional. Posiblemente por falta de una intelectualidad y de dirigencias que, planteándose una mirada y representación más amplia que la localidad o comunidad, tomaran esta categoría y lograran paulatinamente su generalización en la base social ${ }^{16}$. Una nueva construcción de sentido se impone progresivamente, entonces. En ella el concepto de indio se vincula a la idea de progreso y se reserva a los que están más atrasados respecto de los cambios modernizadores que se viven en las áreas industriales, los centros urbanos o los enclaves productivos. De esta manera, de la ubicación del indio en un sistema estamentario se pasa a una estructura social transitiva: se es "indio" mientras se mantengan las condiciones materiales y culturales previas de la vida de los hogares y los grupos a los que se pertenece. Es ahora una categoría de descripción y calificación de carencias y rezagos. Precisemos que la definición de "indio" o indígena, utilizada como equivalente de atraso, es relativa también de otro modo, al depender tal cualificación de quien evalúa una condición social ${ }^{17}$. Ello permite explicar que usualmente los residentes de la precordillera andina calificaban de "indios" a los miembros de las comunidades pastoriles de la alta cordillera, pero ellos cabían bajo esa misma atribución cuando eran vistos y calificados por los chilenos residentes en los centros mineros o en los puertos de la costa (Gundermann 2003).

El siguiente testimonio corresponde al integrante de una familia de la precordillera andina, un hombre que ahora se siente decidida y cabalmente aymara, pero que en su infancia establecía límites nítidos con los residentes de la alta cordillera, diferencias que trazaban una línea fronteriza entre lo indio y lo no indio:

Para la gente urbana hablábamos mal castellano, pero para nosotros era el castellano perfecto. Por lo tanto, eso nos hacía ser diferentes a esos niños. Y para nosotros, en el tema identitario, esos chicos venían del altiplano, eran los indígenas, el "paisano", el "paitoco", el "indio" y todos esos epítetos nosotros los usábamos con ellos. Y ¿de quiénes los aprendimos? Los aprendimos de nuestros hermanos mayores. Pero, fundamentalmente, creo que ellos los aprendieron de los carabineros, del profesor, de la gente que llegó a servir como [oficiales del] Registro Civil en mi pueblo, que eran gente foránea (aymara, hombre adulto, urbano).

El comportamiento utilizado con sus vecinos "indios" cordilleranos, ellos mismos lo vivirían con su paso a las ciudades costeras, tal como revela el siguiente testimonio:

El concepto de ser indígena en aquel entonces era bien simple. Uno era o no era "paisano" [indio], así de simple... Y siempre era típico, se juntaban los niños del barrio y, tradicional, llegaba el grito; yo siempre me acuerdo de ello: ‘¡Ven pa’acá, llegaron los paisanosi' Entonces era como un espectáculo para ellos, bastante. Pero no sé si marca o no marca, pero para mí era una situación que denotaba la diferencia, que notaba la cosa distinta. Digamos [que era] como el alien que llegaba a la pobla[ción] (aymara, hombre adulto, rural).

La temprana definición y asunción de la población indígena regional como "peruana" es el resultado de la intensa integración a la economía extractiva regional y cambios políticos que tienen lugar en la segunda mitad del siglo XIX (salida de la condición económica, jurídica y social de indio), unido más tarde a los conflictos derivados de la anexión del territorio por Chile, entre otros los de nacionalidades (por ejemplo, la violencia nacionalista durante los años del periodo plebiscitario en Tacna y Arica). La concurrencia de estos factores consideramos que es responsable de la temprana y bien definida formación de identidades y alteridades nacionales en Arica y Tarapacá, incluyendo importantes áreas de comunidades aymaras; precisamente aquellas más relacionadas a los centros de actividad económica y administración (enclaves salitreros, puertos de Arica e Iquique).

De lo anterior se deriva que en el sistema de identidades colectivas andinas modernas, las identificaciones locales heredadas del pasado, por una parte, y las nacionales más recientes, por otra, fueron las de mayor significación cultural y sociopolítica, hasta la reciente formación de identificaciones étnicas ${ }^{18}$. Puede presumirse que en un sistema de identidades colectivas más complejo como el de ahora, las identificaciones sufren ajustes y cambios por relación con el pasado. Quizá el más notorio es el de la cerrada asociación que se crea entre 
identificación local y étnica (la cultura local es la afirmación, el pilar que da fundamento cultural a lo étnico). Pero que también puede tomar la forma de tensiones, conflictos y contradicciones nuevas. Por ejemplo, la defensa de las culturas locales de las comunidades ha sido usada para oponerse a esa representación y prácticas de una cultura aymara bi o trinacional, oposición en la que entonces concurren tres niveles de identificación en controversia. No puede extrañar, por tanto, que los procesos étnicos contemporáneos estén en el norte de Chile histórica y sociológicamente relacionados con los relativos a las identificaciones nacionales ${ }^{19}$. Lo estuvieron en el pasado y lo están en el presente: como parte de relaciones interétnicas (chilenos que asumen estar en interacción con indígenas, pero al mismo tiempo con "bolivianos", por ejemplo) y también intraétnicas (discusiones y tensiones entre aymaras chilenos y bolivianos) $)^{20}$.

\subsection{Ideas, nuevos y renovados estereotipos y prejuicios, otras condiciones}

La vieja noción de "indio" ha perdido legitimidad, aunque permanece como una representación todavía activa, que se manifiesta en la vida social con, aparentemente, menos frecuencia que antes. Para ser precisos, desaparece como formación discursiva hegemónica y, por tanto, dominante. Pervive como referencia de significado en el sentido común de la población regional, especialmente la no indígena, que no ha reelaborado, o lo ha hecho muy parcialmente, su idea de lo indígena con arreglo a los nuevos aires multiculturales. Según los relatos reunidos, a veces se hace presente en las interacciones sociales. Por ejemplo, en los grupos de trabajo o en la vida poblacional, aunque posiblemente no con la recurrencia de antaño y, por cierto, con mayor controversia por parte de quienes reciben esta apelación. La siguiente declaración refiere una situación no excepcional presente en las faenas mineras de la región:

Bueno, en el mismo casino uno ve, no son los jefes, sino los mismos compañeros de trabajo cuando a uno lo tratan de "indio", o cosas así. Como al casino van todos, de repente uno escucha cuando las personas te tratan de -indio tal por cual-; o el mismo sobrenombre, a uno le ponen "llamo". A veces uno hace oídos sordos, pero en el fondo igual se siente mal. Como que todavía queda esa discriminación con los aymaras (aymara, hombre adulto, urbano).

La experiencia les ha llevado a distinguir con fineza cuando se trata de una interjección jocosa, un insulto o una adjetivación sin animosidad pero agraviante, y a actuar en consecuencia. Entre otras posibilidades de respuesta están la omisión (desentenderse), la ilustración (la aclaración del tipo: "Indios son los de India, yo soy aymara"), la violencia verbal de retorno (por ejemplo: "¡Aquí en el norte te damos de comer!") o la respuesta física de agresión (replicar trenzándose a golpes). Regularmente consideran, entonces, contraargumentos basados en la unidad o diferencia nacional, étnica, regional o la genérica a la dignidad de los seres humanos. Algunos testimonios ilustradores son los siguientes:

¡Paisana!, ¡india! Los niños más que nada dicen eso. [Respecto a] la reacción de los adultos cuando los niños te molestaban, tú les reclamabas a los papás y no hacían nada, solamente se reían y se burlaban (aymara, mujer adulta, rural).

Hay discriminación de algunos vecinos que no son netamente de pueblos originarios. Por ejemplo, he escuchado comentarios, a nosotros nos dicen 'indio', pero yo les digo: 'Señor, usted está equivocado, yo no soy indio, soy boliviano (aymara, hombre, adulto, urbano).

...hay compañeros que tiran tallas y dañan a otros compañeros de trabajo que son de otras costumbres. Por ejemplo, hay jóvenes que llegan y te empiezan a tratar de "llamo" o empiezan a gritar: "¡Peruano!”. El muchacho lo toma como un chiste, pero de repente hay momentos que también hieren, se siente mal uno (aymara, hombre, adulto, urbano).

Si previamente las formas de contestación al estereotipo de "indio" se apoyaron en argumentos de igualdad (iguales seres humanos, de una misma nacionalidad o región, igualmente ciudadanos) o equivalencia (de Bolivia, aunque también con derechos; con orígenes indígenas, pero con el mismo valor como personas) este cuerpo de ideas se ha 
enriquecido ahora con posicionamientos de diferencia. Se está asumiendo una nueva constelación de significados, con base en nociones de multiculturalidad, que los andinos hacen propia y que también irradia hacia la población regional no indígena. De ellas participan los conceptos de etnia o cultura y las de pueblo, pueblo originario, minoría lingüística o incluso nación. La siguiente declaración describe momentos del proceso de incorporación de esas ideas y algunas de las fuentes de las que se nutre:

Si nosotros queremos revivir el concepto identitario aymara tenemos que creernos el cuento de ser aymara. Y para eso había que practicar y fomentar ese discurso, y nosotros ahí nos declaramos al tiro apolíticos de cualquier ideología externa y que nuestra lucha era por formar la ideología de la indianidad. Ahora, esa ideología de la indianidad, por supuesto, no fue un descubrimiento ni un discurso patentado por nosotros. Lo tomamos porque ya el Consejo Indio Sudamericano, con las organizaciones peruanas y bolivianas, con ciertos ribetes de identidad indígena, ya lo habían abordado. Y en Perú en especial hubo un profesional, Virgilio Roel, que sacó varios panfletos chiquitos de discursos proselitistas sobre la indianidad, que para nosotros fueron como el pan caliente para reforzar los conceptos ideológicos medio desnudos que teníamos en esa época. Nos dio fuerza, porque ahí nos hablaba sobre el tema de partir de lo más puro del mundo andino, rescatar la pureza del Tahuantinsuyo, practicar los principios básicos del mundo andino, ama sua, ama qella, ama llulla, no robar, no mentir, no ser flojo (aymara, hombre adulto, urbano).

La formación discursiva de la multiculturalidad ha irradiado y se ha hecho prevaleciente entre los aymaras. Un papel principal en su difusión en la zona aymara lo jugó la dictación de la Ley Indígena No 19.253 y su puesta en ejercicio a través de la acción de la Corporación Nacional de Desarrollo Indígena (CONADI) ${ }^{21}$. Sus funcionarios se empaparon desde un inicio de las nuevas nociones o ya las traían por el hecho de haber sido partícipes de movimientos indígenas y por haberse implicado en la gestación de la ley ${ }^{22}$. En el norte del país el control de CONADI lo obtuvieron dirigentes y profesionales aymaras, en un caso, y atacameños en el otro. Ellos fueron activos militantes de estas nuevas ideas en comunidades y agrupaciones de base que no las conocían o las manejaban muy incipientemente. Cuando obtuvieron poco eco en su accionar, como en la precordillera andina, entonces hicieron valer la necesidad de la identificación étnica como condición de asignación de proyectos y recursos económicos demandados por las comunidades y asociaciones, lo que favoreció de manera determinante la irradiación de una concepción etnificada de sí mismos entre la población aymara y nociones acerca de sus derechos colectivos o de ciudadanía étnica.

En el norte chileno, las nociones de extranjero e indio se asocian frecuentemente. Los que viven en las zonas interiores, se piensa, son peruanos o sus padres lo fueron, o son bolivianos por su proveniencia o porque lo parecen. Pero, también, son indios por su marginalidad geográfica relativa, la pobreza material que ponen de manifiesto o las formas de vida campesinas que los caracterizan en las montañas andinas. Recientemente, inclusive desde los indígenas chilenos han surgido estipulaciones que diferencian muy claramente a los de acá de la cordillera respecto de los de allá (el altiplano boliviano). La inmigración de aymaras provenientes de Bolivia ha sido persistente en la historia regional, especialmente hacia Arica. Respecto de ello, la población aymara regional de los valles ha adoptado posiciones diferenciadoras no carentes de animosidad:

Hoy día un aymara chileno tiende a discriminar al que es boliviano. $\mathrm{Y}$ el de precordillera discrimina al del altiplano, y el del valle al de la precordillera y así cada uno se discrimina (aymara, hombre adulto, urbano $)^{23}$.

La transformación durante la década de 1990 de la frontera entre Chile y Bolivia como un corredor de cocaína y derivados, además de la permanencia del contrabando histórico, ha involucrado la participación de personas, familias y redes aymaras en estas actividades ilícitas, lo que ha favorecido el surgimiento de nuevos estereotipos y prejuicios ${ }^{24}$. Se ha creado el estereotipo del aymara como traficante. Por cierto, esto no habría sido posible de no mediar una prolongada construcción mediática; por ejemplo, a través de categorías como "cartel andino" o semejantes en la televisión, las radios y 
los periódicos regionales ${ }^{25}$. La figura del aymara traficante (en realidad, transportadores o "burrero" la mayoría de las veces) no ocurre aislada de otras referencias de sentido. Con frecuencia se enlaza con "indio", "paisano", "paitoco", "llamo" y "boliviano" que denotan categoría social inferior, distante y ajeno de allá de la cordillera, y extranjero. El conjunto no carece de algunas notas racistas. De ahí que "indio", "aymara", "traficante" y "boliviano" son categorías que forman parte de una misma representación estereotipada y prejuiciosa hacia la población andina regional o con ese origen. $\mathrm{Al}$ respecto:

Con el solo hecho de tener nosotros el apellido Mamani, Challapa, nos tienen como traficantes, esa es la primera impresión que ellos tienen. Siempre va asociado a que nosotros somos traficantes. Por ejemplo, cuando subimos [a las faenas mineras] nos dicen: 'Oye ¿cuántos kilos te trajiste?, ¿trajiste algo?, ¿vas a bajar algo?' Es como esa la realidad; es lo primero que piensan. Bueno, cada uno tendrá sus razones, pero yo creo que no todos somos así (aymara, hombre adulto, urbano).

Estas no son categorías de un sistema de ideas empleado solo por los no aymaras o un sector de la población regional; también a ellas se acude desde el interior de la propia sociedad indígena regional. Aymaras y quechuas de los valles, precordillera andinas y urbanos con frecuencia emplean estas nociones para describir, criticar y hasta denostar a los aymaras del altiplano o a los de origen boliviano. En particular cuando quieren referirse al progreso económico de algunos de ellos en el comercio y el transporte, que les parece demasiado rápido para explicarse solo por sus habilidades personales en actividades económicas y negocios lícitos.

Otra situación que amerita análisis se refiere a una disputa, a la vez política y cultural, que en último término deriva en una competencia por oportunidades y recursos. Ella opone a los aymaras chilenos, especialmente aquellos de la zona precordillerana andina de Tarapacá y Arica, con los aymaras de Bolivia afincados en la zona, por la condición más o menos genuina de la cultura que unos y otros cultivan. Los aymaras chilenos discuten el reconocimiento oficial y la visibilidad que han ganado las expresiones culturales de los aymaras de Bolivia, en desmedro de las expresiones regionales consideradas como legítimas y auténticas de la zona ${ }^{26}$.

El mejor ejemplo de lo anterior es el Carnaval de la localidad de Azapa en el valle homónimo y, más recientemente, el Carnaval de Arica. Parte del éxito público urbano y apoyo de autoridades y agencias públicas proviene del carácter multitudinario y festivo, por oposición a aquel más local comunitario de las expresiones aymaras regionales. El desarrollo de esta controversia lleva ya bastante tiempo, tanto como la acción que en materia cultural indígena empezó a promover en la zona la CONADI desde la década de 1990, relacionada con la importancia etnopolítica que adquieren las delimitaciones y la tipificación de lo cultural aymara. Un par de declaraciones al respecto:

Yo aceptaba las diabladas [baile religioso] hasta hace poco. Las diabladas está bien, porque [se han hecho propios a La Tirana, por ejemplo y] me gustaba. Pero ahora derechamente estamos con sayas, caporales y tinku [bailes provenientes de Bolivia]... Veo los titulares de los diarios, veo los jardines infantiles cómo los tergiversan. No, yo creo que está manejado... (quechua, hombre adulto, urbano).

Y del mismo estilo:

Nunca se ha tocado [en Chile]. Eso es tarka, nunca se ha bailado tinku, sambo caporal como se presenta en Santiago. La precordillera, el folklore de la precordillera del norte de Chile nunca, jamás [se ha valorado y considerado], entonces, ¿cómo es la cosa?, ¿quién miente?, o ¿quién influye (aymara, hombre adulto, urbano).

En esta discusión las posiciones no son simples. Desde las agencias públicas y autoridades se advierte la extranjeridad asociada a una de las vertientes de lo cultural aymara presente en la zona. En un área en que se han mantenido delimitaciones, fronteras políticas y estipulaciones culturales de chilenidad, debería esperarse que se apoyaran variantes regionales de lo cultural aymara. Pero, por otra parte, con los nuevos aires de tolerancia cultural les interesan las posibilidades que ofrece la masividad de la manifestación aymara de allende los Andes. Los aymaras oriundos de la región, de los que debería esperarse 
mayor apertura, habida cuenta de una historia de prejuicios que ellos mismos vivieron al considerárseles indígenas, se presentan ahora como activos promotores de diferenciar y, en ciertos aspectos, segregar entre lo propio y lo aymara extranjero, considerando que en Chile reciben oportunidades y privilegios que no les corresponden.

Para funcionarios, intelectuales y activistas aymaras las opciones son claras. Para ellos la expresión más completa, profunda y brillante de lo cultural aymara proviene de las regiones aymaras bolivianas. Por lo tanto, es un contrasentido relegar estas expresiones a un segundo lugar o al anonimato en favor de la variante, más modesta, híbrida y en rápida transformación, de lo cultural aymara regional. Sus ideas acerca de la etnicidad aymara los llevan así a un terreno de controversia con el regionalismo aymara y el nacionalismo chileno. $\mathrm{Y}$ algunos lo hacen desde el interior de agencias públicas intentando, a la larga sin éxito, un delicado equilibrio entre etnonacionalismo panaymara y presiones que abogan por un etnicismo de menor alcance.

\section{Redistribución Regional de la Población Aymara, Esferas Sociales e Interacciones}

Bastante por sobre los dos tercios de la población aymara regional vive en centros urbanos. Arica en primer lugar, pero también Iquique, Alto Hospicio, Pozo Almonte, Pica-Matilla y Putre reúnen a decenas de miles de personas que censalmente se reconocen pertenecientes al pueblo aymara. Algo más de un millar, que seguramente aumentará en los recuentos venideros, integran la presencia regional quechua de Arica-Parinacota y Tarapacá (INE - Orígenes 2005). Áreas agrícolas con una presencia aymara particularmente densa se encuentran muy próximas a la ciudad de Arica; una de ellas, la del valle de Azapa, culmina allí donde empieza Arica en el borde costero. Por ello es que el vínculo de estos valles con la capital regional es continuo e intenso. De esta manera, las relaciones entre personas y grupos aymaras (y quechuas, amén de afrolatino descendientes y de algunos mapuches residentes en la zona) con la mayoría no indígena es hoy día un fenómeno eminentemente urbano.

La vida urbana posibilita tipos, profundidad y frecuencias de interacciones y relaciones interétnicas muy distintas a las de la vida pueblerina o comunitaria rural de antes y de ahora. Al mismo tiempo, lo decisivo no está hoy representado por interacciones en medios rurales, como pudo serlo en el pasado. Por lo demás, aquellas eran más bien específicas y delimitadas. Ellas no han desaparecido, pero sí disminuido en importancia relativa y cambiado en las características que adoptan.

En una zona como Isluga o Cariquima, en la alta cordillera de la Región de Tarapacá, todavía a mediados del siglo XX el contacto con personas no andinas (k'ara o "blancos" de Bolivia y Chile) era una rareza. La mayoría no hablaba castellano o este era muy incipiente, por lo que tales interacciones estaban más bien reservadas a los varones adultos, usualmente con mejor manejo de la lengua nacional. Con las comunidades indígenas bolivianas de más allá de la frontera las relaciones eran comunes. No obstante, al quedar definidas unas y otras como andinas e indígenas, no puede hablarse de relaciones interétnicas, aunque sí de relaciones entre indígenas pertenecientes a distintos países. Ahora bien, un vínculo paradójico es el de los nexos de estas relativamente más aisladas comunidades de la cordillera con los valles y oasis occidentales. Las relaciones con estas áreas, por trabajo e intercambio de productos, se realizaban sobre la base de compartir aspectos culturales (diversas prácticas y códigos de relación). No obstante, se consideraban a sí mismos categorías muy contrastadas de población, aunque intersectadas culturalmente.

Las relaciones de personas aymaras (también quechuas y chipayas) con no indígenas ("blancos" o "chilenos") son hoy frecuentes y hasta cotidianas en las zonas rurales andinas. El lugar y los contextos sociales de interacción en estas zonas presuponen la condición indígena de alguna de las partes, por lo cual la relación que se establece adquiere sentido de interétnica: un turista cuando llega a un poblado andino de altura en los parques nacionales existentes en el área; un funcionario municipal cuando atiende trámites o requerimientos de pobladores de los Andes; los profesionales de un programa de fomento estatal al tratar con miembros de una Comunidad Indígena; los nexos entre agricultores vecinos en que se conoce que uno es "andino", "paisano", indígena o aymara; un carabinero que atiende la queja de un poblador de una comunidad cordillerana, etc. Antes "indios", hoy con mayor frecuencia "aymaras", los khara "blancos", "rotos" o "chilenos" - a veces en el pasado: wirakochas - se ven impelidos a asumir que tratan con personas cultural y socialmente 
particulares a través de nuevas nociones y categorías que expresan diferencias sociales, raciales y/o culturales:

La relación con los no indígenas, yo creo que forzadamente es muy buena porque los no indígenas son los menos, son la minoría [en las zonas rurales]. El no indígena acá en Putre es minoría. Entonces obviamente no tiene la opción de poder imponer su criterio o su forma, porque acá es territorio aymara. Es muy potente, es muy fuerte la expresión indígena, están las fiestas tradicionales, está el empoderamiento de las organizaciones comunitarias, el centro de padres y apoderados, liderado por un indígena. Las dos juntas de vecinos [y la comunidad indígena] lideradas por un indígena. Entonces, hay capacidad expresiva, hay posicionamiento de la comunidad indígena acá. En ese sentido, por tanto, aquel que llegue acá, no indígena, tiene que transar, tiene que conversar con las personas, con las autoridades (aymara, hombre adulto, rural).

En cambio, en zonas no convencionalmente andinas, como los valles bajos cercanos a Arica, donde los aymaras chilenos y bolivianos han llegado a asentarse y donde hay una activa circulación de personas, ese carácter cuasiinmediato de lo étnico en las interacciones sociales tiende a perderse. Para que se manifieste, dependerá de que una de las partes lo explicite, lo reconozca en el interlocutor o en la interlocución, o lo demande. Y ello no es automático, o no hay necesidad ineludible que así tenga que ocurrir. Por ejemplo, en las interacciones que se establecen en el mercado de consumo personal o familiar (compra y venta de bienes de consumo más o menos inmediato) es muy poco probable que lo étnico vaya más allá de un eventual presumir estar en presencia de un aymara o ese aymara sentirse como tal y advertir que su interlocutor no lo es. Incluso si se trata, como es común en los centros urbanos del norte del país, de mercadillos y terminales agropecuarios, la considerable participación aymara en este rubro de comercio no concita sino ocasionalmente alguna incidencia práctica de lo étnico. Se podría decir así que a más efímeras y específicas son las interacciones, menos probabilidades de reconocimiento de diferencias étnicas se dan, a menos que ellas tengan orientaciones y objetivos que impliquen directamente lo étnico. A medida que la copresencia se hace más continua o reiterada (por ejemplo, en una escuela pública, un comité de vivienda, un club de futbol, una cuadrilla de trabajo de la construcción, en la convivencia en el barrio) se dan condiciones para, primero, el conocimiento de los otros como sujetos étnicos "aymaras" o "indios", y de esos otros como sujetos no aymaras. Y, segundo, para que en las interacciones (supuesto ese conocimiento) intervenga o se haga intervenir conscientemente lo étnico aymara. Una mirada francamente optimista de la intensidad de estas relaciones queda referida en la siguiente declaración:

Los veo unidos, están trabajando en conjunto [aymaras y no indígenas]. Ahora yo le voy a decir una cosa: los que no son indígenas quieren ser indígenas por el asunto de las costumbres, porque les gusta la música, las tradiciones de los pueblos. Crecen ahí y se sienten bien. Cuando están cerca de nosotros se sienten bien porque están dentro del grupo. Hay mucha gente que nosotros acogimos como refuerzo en la parte deportiva, y está contenta porque los llevamos a Belén, la música, la banda: 'Ay, yo soy de Belén', dicen (aymara, hombre adulto, rural).

Probablemente en la mayoría de los ámbitos de interacción social de los que participan las personas aymaras se encuentre etnificación de las interacciones sociales, pero solo cuando existen condiciones para ello y, aun así, la activación de lo étnico está lejos de ser algo que necesariamente vaya a darse en todos los casos. Un requisito importante es que se hayan producido estados de reconocimiento extensivos, sociales y no simplemente individuales y contingentes, para que se dé el presupuesto de una relación interétnica. El profuso campo de relaciones que se dan entre las personas y organizaciones aymaras con los integrantes de organismos públicos, gobiernos locales, instituciones de justicia, programas especiales en educación y salud, etc., pueden suponer lo étnico como dimensión estructurante de la relación. Es posible entonces que en estos casos toda la interacción quede de partida étnicamente definida. 


\section{3. Ámbitos de Interacción y \\ Algunas Características que Adoptan las Relaciones Interétnicas}

\subsection{Relaciones entre aymaras y agentes públicos}

Las interacciones más sistemáticamente etnificadas entre aymaras y otros agentes sociales son aquellas que mantienen con agencias públicas y sus funcionarios. En especial, con los organismos que están mandatados para ejecutar la política indígena del país: la CONADI, el Programa de Educación Intercultural Bilingüe (PEIB) del Ministerio de Educación o su equivalente de Salud Intercultural en el Ministerio de Salud. No podría ser de otra manera, ya que las relaciones se establecen entre unos como agentes públicos y otros que en esas interacciones se posicionan como aymaras. La interlocución, coordinación, negociaciones, acuerdos, traspaso de información, demandas, controversias, transferencias de recursos, capacitación, asesorías, reclamos, etc., se realiza entre sujetos consciente y explícitamente posicionados como agentes públicos o mandatados por estos (como los ejecutores privados de proyectos) respecto de aymaras (personas, familias o comunidades indígenas) a quienes asumen como sujetos étnicos.

Los agentes públicos que efectivamente se relacionan con los aymaras en la ventanilla de la oficina o en terreno son, en general, personas oriundas de la región norte y, por lo tanto, partícipes de representaciones que regionalmente se han elaborado y se mantienen acerca de los integrantes de este pueblo originario. Como parte de ello, suelen tener ideas críticas respecto de la condición aymara, como que no son indígenas genuinos, en el sentido de que culturalmente no se diferencian en forma notoria de cualquier otro ciudadano del país, o que si lo fueron ya no lo son, o que racialmente son mestizos o muy poco indígenas desde un punto de vista biológico:

Entonces, te das cuenta que en el fondo mucha gente es farsante. Les va a llegar un momento donde digan: 'Oye, despierta; te estai pegando los carriles y en el fondo no eres lo que tú crees ser; te estás aprovechando porque tienes becas, tienes beneficios, pero cuando te quiten todos esos beneficios vamos a ver si te consideras [aymara] como dices que te consideras (no aymara, hombre adulto, urbano).
No es raro escuchar a funcionarios públicos que insinúan o plantean derechamente que la discriminación positiva es una forma de privilegio que distorsiona la igualdad de oportunidades que se debe tener con todos los chilenos sin excepción. Algunos pueden intentar una posición neutra, limitándose a actuar dentro del espacio de atribuciones y competencias otorgado por la agencia pública en la que trabajan. Otros pueden sostener puntos de vista mucho más favorables, entre ellos los funcionarios públicos aymaras, aunque entre estos tampoco falta quien tiene posturas críticas respecto del actuar de sus paisanos frente a las reparticiones del Estado ${ }^{27}$. No obstante lo dicho, más allá de sus ideas, estereotipos y prejuicios, los funcionarios no pueden sino actuar con arreglo a lo que se les ordena e instruye, en marcos de programación previstos y siguiendo procedimientos razonablemente establecidos. Una cuestión difícil de evaluar es cuánto de las ideas de las que son portadores, más allá de la cultura institucional de la que forman parte, o de las orientaciones de acción que se les ordena cumplir, interviene y afecta sus actividades con los aymaras. Estos últimos dan a entender que la discriminación existe entre los funcionarios públicos. Aquellos normalmente rechazan estas imputaciones arguyendo que se limitan a actuar dentro de lo que sus organismos les permiten y con arreglo a lo que les mandatan.

Una gama muy variada de servicios y bienes son provistos por las agencias públicas a los aymaras. Muchas de ellas están dirigidas a las personas u hogares. Otras operan con grupos y organizaciones, como las Comunidades y Asociaciones Indígenas, Juntas de Vecinos o comités de distinto tipo (por ejemplo, de vivienda, agricultura, emprendimientos económicos asociativos); ya sea que se dirijan a alcanzar resultados colectivos (una sede social, por ejemplo) o beneficios dirigidos a los integrantes del colectivo (distribución de alguna donación, trabajo temporal para los miembros de la organización). A estas modalidades de trabajo estatal suele denominársele etnodesarrollo y su despliegue sigue una lógica de proyectos. Más ampliamente considerado, las personas y familias aymaras son activas demandantes de servicios, subsidios y bienes provistos por reparticiones públicas. Por ejemplo, los esfuerzos por obtener subsidios de vivienda básica urbana, o titulación de sitios urbanos para autoconstrucción resultante de "tomas", son algo en lo que se ha dado muchísima actividad aymara desde 
la década de 1990 en adelante. Otro tanto respecto de los subsidios familiares y otros instrumentos de apoyo a las situaciones de pobreza que muchos hogares aymaras buscan activamente incorporarse.

Las relaciones entre aymaras y agentes públicos se encuentran sujetas a reglamentación, planificación, presupuestos, registros, protocolos, definición de coberturas y tiempos de operación a los cuales debe atenerse la acción de los servicios estatales. El trabajo con base en proyectos es uno de los mecanismos en que con más propiedad se impone el poder burocrático sobre los dirigentes y personas aymaras. En su desenvolvimiento se verifican también los límites hasta los cuales llegan las capacidades de gestión de las organizaciones aymaras. Es un ámbito de relaciones en que muchos dirigentes aymaras han buscado manejar las restricciones que les impone la lógica de los proyectos. También han activado, como parte de estas relaciones, intereses individuales o colectivos bajo términos particulares.

Debido a lo anterior es que los vínculos entre aymaras y agentes públicos no puedan verse como un flujo unidireccional en el que los indígenas son simplemente receptores de bienes y servicios ("beneficiarios" y "usuarios") provistos por el Estado en el marco de la política pública indígena o de atención a la pobreza. Son también relaciones de negociación, disputa, control e incluso conflicto en uno y otro sentido. Por parte de los agentes públicos con frecuencia se critica el no cumplimiento de compromisos y acuerdos por parte de las comunidades y se discute el manejo que hacen de recursos financieros de proyectos y las rendiciones de cuentas. Por el lado de las personas aymaras y sus dirigentes se critica el trato a veces autoritario o incluso agresivo, o distante y displicente de los funcionarios públicos, la poca eficiencia en la respuesta y tramitación de solicitudes o en la gestión del "papeleo" de una iniciativa de desarrollo local, pero también poca transparencia y eventualmente discrecionalidad en las decisiones.

Las relaciones entre agentes públicos y aymaras pueden verse como políticas en un doble sentido. Externamente, porque en la acción pública hacia los aymaras, las prioridades, las asignaciones presupuestarias o la definición de los destinatarios preferentes están mediados por sujetos con compromisos y poderes políticos identificables: jefes de servicio, alcaldes, concejales de los municipios andinos, consejeros nacionales indígenas, parlamentarios de la región, gobernadores e intendentes actúan siguiendo criterios e intereses de gobierno y de los partidos de la coalición gobernante o de la oposición a ella, según el caso. Los funcionarios públicos indígenas tampoco escapan a esto:

Normalmente tenemos autoridades que tienen miradas políticas, política electoral más que de política institucional. Quiero ser un crítico constructivo de la CONADI, a mí me gusta el modelo de la CONADI, me gusta la inspiración que tuvo la CONADI en sus inicios; lo que no me ha gustado es cómo se ha desarrollado hasta ahora, en el sentido de que se ha generado un clientelismo que enfrenta a indígenas que son urbanos, con indígenas que son rurales. [Estos últimos] no tienen la oportunidad de poder competir con los otros, que viven permanentemente relacionados con las instituciones de financiamiento como el FOSIS, Orígenes, INDAP, son los mismos que se repiten (aymara, hombre adulto, urbano).

Internamente a los aymaras las relaciones también tienen una dimensión política, porque es en la interacción con las agencias públicas, sus inversiones y servicios que normalmente se evalúa la gestión y el éxito de los dirigentes de base y representantes ubicados en niveles más altos. Que un dirigente de comunidades indígenas aymaras prolongue su mandato como representante de un grupo, logre conducción y gane liderazgo depende en buena medida de los resultados que obtenga de su relación con los agentes públicos:

Muchos quieren, obviamente, destacarse dentro del liderazgo indígena, ni siquiera grandes líderes, sino que tener cierta capacidad de negociación. De repente juntar grupos para reclamar o meter bulla en algún lado les trae dividendos políticos y traducidos inclusive en participación o nombramiento de cargos políticos, para obtener un espacio, unas "luquitas" [algo de dinero] por ser reconocido como indígena y tener cierta capacidad negociadora en el ambiente (aymara, hombre adulto, rural).

Algo de lo descrito y algunas de sus desviaciones y vicios son indicados en la siguiente declaración: 
Veo, por ejemplo, un segmento de dirigentes muy ligados, lamentablemente, a mi juicio, a los segmentos políticos que tenemos, lo que para nada comulga con nuestra raíz de identidad de pueblo. Veo a muchos dirigentes tratando de mantenerse o aflorar como dirigentes no por la lucha de su pueblo indígena, sino por ver cómo llegan a tener algún prestigio para que algún partido donde pretenden entronizarse o incrustarse los reconozca. Y eso muchas veces se contradice con la lucha que uno tiene que brindar por su comunidad o por su pueblo. Eso a mí me ha hecho durante todos estos años no vincularme a ningún bando político. De hecho yo creo que soy uno de los pocos dirigentes de antaño que no me he vinculado con ningún partido político. Yo he sido reacio. Casi todos los dirigentes más antiguos, de alguna manera se vincularon a partidos políticos (aymara, hombre adulto, urbano).

El mismo entrevistado se refiere a la relación de ciertos dirigentes con las bases:

En un comienzo emergió mucha idea por constituir asociaciones y, sobre todo, comunidades indígenas en pro del saneamiento de títulos de derechos de agua, de tierras. Pero, sin duda, al día de hoy nos estamos dando cuenta de que han proliferado estas iniciativas no por la necesidad y la demanda en conciencia de los miembros de esa comunidad, sino por el interés de algunas personas de la comunidad que se entronizan como dirigentes para obtener beneficios y proyectos más de título familiar, individual, que para la comunidad. O sea, de hecho, hoy en día uno de los grandes problemas que tenemos acá es que la mayoría de los miembros de las comunidades reclaman que los dirigentes sacan [adjudican] y ejecutan proyectos, pero jamás el beneficio les llega a ellos. $\mathrm{Y}$ ven [por el contrario] que el beneficio está llegando generalmente al que está asumiendo el cargo y a algunos compinches, entre comillas, que están alrededor de él, que son más adictos (aymara, hombre adulto, urbano).

\subsection{La economía de los aymaras y las relaciones interétnicas}

Las imágenes convencionales de la tradicionalidad social y cultural aymara suelen asociarse, sobre todo, a la economía rural agraria. Cuando se evoca la figura del "indio", la relación que se hace es con esa vida rural orientada a las actividades agropecuarias. Pero esta se ha transformado fuertemente durante las últimas cuatro o cinco décadas. Los cambios más importantes son la redistribución de la población rural, el aumento de sistemas de doble residencia rural y urbana, la disminución de las economías propiamente campesinas, una más definida orientación de la producción al mercado y, por consiguiente, la monetarización de las relaciones económicas y el aumento de las relaciones asalariadas. A este panorama se suman las actividades interfronterizas ilícitas. Sobre esta nueva ruralidad se forma el esquema de relaciones inter e intraétnicas que reseñamos ${ }^{28}$.

La economía rural aymara es preponderantemente agrícola. El transporte y la intermediación de mercado que conecta las áreas agrícolas con los centros urbanos regionales son realizados principalmente por aymaras. Es muy notoria su presencia en los mercados de abastos, las ferias libres o los terminales agropecuarios de las ciudades del norte del país. De ahí que pueda decirse que la economía agraria campesina (o empresarial en pequeña escala) de toda la zona norte es básicamente controlada por aymaras, desde la producción hasta la llegada de productos al consumidor final. De este modo, las relaciones que en esta esfera se dan en las áreas rurales son intraétnicas, pero también las hay interétnicas: de aymaras con otros indígenas locales (quechuas o, a veces, afrodescendientes, como en Azapa) e inmigrantes temporales o definitivos (quechuas de Perú, chipayas de Bolivia) ${ }^{29}$. También de aymaras con otros habitantes rurales que no se reconocen como indígenas, sino como ciudadanos chilenos del común. En cuanto a las relaciones intraétnicas aymaras, se han construido alteridades socialmente relevantes que diferencian a aymaras chilenos de bolivianos.

La integración económica aymara a la región se caracteriza por una notoria tendencia a la autonomía económica (campesinos, pero también pequeños comerciantes, transportistas, talleristas, oficinas de contabilidad, etc.) y también, más recientemente, por una algo mayor participación en el trabajo asalariado. 
El aumento del asalariamiento aymara es llevado a efecto, principalmente, por las generaciones de nacidos en los medios urbanos, normalmente con mayores niveles de educación formal y a veces con formación técnica o profesional. Se insertan en la administración pública, como empleados de comercio, trabajadores en empresas de servicios, choferes en empresas de transporte y obreros en actividades industriales como la minería o la generación eléctrica. En esos espacios laborales sus orígenes indígenas pueden llegar a ser conocidos y en esos casos se activan interacciones en que lo indígena es aludido o implicado. En ciertas faenas mineras, por ejemplo:

En la sal [una gran mina de sal comestible al sur de la ciudad de Iquique] no se ve mucho aymara, en el yodo sí porque trabaja harta gente de Pozo Almonte y ahí casi la mayoría son aymaras. Son de Colchane, de Cariquima, casi la mayoría de la gente en Pozo Almonte son aymaras. [Están] dentro del ámbito laboral minero en distintas áreas de trabajo: por ejemplo, hay administrativos, operarios, operadores de maquinarias, una buena cantidad. Por lo menos es la experiencia que yo tengo ya que he estado en distintas minas, en Antofagasta, Pozo Almonte, ahora último estuve en Collahuasi, y ahí en Collahuasi es donde más se ve gente [indígena], en distintas áreas, no solo como operarios, sino que también en áreas administrativas (aymara, hombre adulto, urbano).

En la gran minería cuprífera regional se ha testimoniado una variedad de formas de interacción entre aymaras y no aymaras: desde indiferencia respecto de orígenes o pertenencias étnicas, hasta el pleno conocimiento de ello. En este último caso puede darse cercanía y amistad, así como distancia social, prejuicio y animosidad. En algunas situaciones, posiblemente, discriminación laboral. En los trabajadores de planta de las grandes empresa mineras estas últimas conductas, sean verbales, peleas con agresión física o actos de perjuicio laboral, no son toleradas y todos se cuidan de no ser sorprendidos en una discusión subida de tono o en una pendencia, por el riesgo de ser expulsados de un trabajo bien remunerado y con diversos beneficios y garantías. En las empresas contratistas el ambiente laboral está sujeto a menos controles, por lo que es aquí donde con más frecuencia se harían presentes situaciones de acoso o abuso laboral en que lo étnico es un elemento de la causa. Como expresión de discriminación laboral se señala que a trabajadores aymaras un capataz suele darles los trabajos que nadie quiere, por tediosos o pesados. Como interacciones con presencia de prejuicios se informa la recurrencia de bromas, puyas y provocaciones en las cuadrillas de trabajadores en que se alude al tráfico de drogas, a la eventualidad del origen boliviano o a la figura del "indio" carente de civilización. Un importante porcentaje de trabajadores en la minería viene de regiones meridionales de Chile y, como producción de alteridad, es frecuente que sean estas personas quienes mayormente aludan al color de la piel, personalidad reservada, extranjeridad, condición de "indio" y aboriginalidad andina de los trabajadores aymaras con que laboran.

Los campesinos aymaras que contratan regularmente trabajadores y los pequeños empresarios aymaras urbanos (en el comercio y transporte) o que prestan servicios a empresas (mineras, entre otras) ocupan pocos trabajadores o empleados no indígenas. Con frecuencia se apoyan en relaciones familiares para contar con personal sujeto a condiciones y trato laboral informal:

La mayoría de los contratistas aymaras que yo conozco buscan su gente, gente aymara. Yo creo que los buscan porque les tienen más confianza; no contratan sureños, en las empresas que yo conozco. Incluso, yo me he hecho amigos de algunos contratistas, dueños de maquinarias y de camiones y tienen su gente, incluso gente extranjera, de Perú, de Bolivia. No sé por qué será, pero es así: ellos contratan su gente (aymara, hombre adulto, urbano).

También acuden a inmigrantes temporales o a quienes realizan permanencias más prolongadas en Chile. Estos trabajadores normalmente son indígenas: quechuas y aymaras peruanos, aymaras bolivianos, chipayas bolivianos y quechuas de regiones interiores de Bolivia (por ejemplo, de zonas mineras deprimidas). Se trata de relaciones trabajador-patrón que, a la vez, adoptan el carácter de interétnicas y entre extranjeros. Estos trabajadores indígenas usualmente no cuentan con permisos de trabajo, a veces son ilegales, aceptan sistemas de 
remuneración combinados de salario en dinero, más alojamiento y alimentación. Dada la precariedad, informalidad y a veces clandestinidad con que llegan, en los empleadores aymaras encuentran alguna protección, acogida y condiciones de trabajo que les acomodan: trabajos temporales, con hospedaje, en actividades con las que pueden estar familiarizados. Ello también tiene diversos costos: bajos salarios, trabajo esforzado, trabajo en aquello para lo que no se encuentran otros trabajadores, jornadas prolongadas, a veces engaños y malos tratos. Aunque para nadie sería desconocido que son relaciones entre personas indígenas o que los que llegan buscando trabajo son indígenas, solo ocasionalmente la condición interétnica de estas relaciones económicas sería explicitada:

En las raimas [recolecta de aceitunas en el valle de Azapa], los parceleros prefieren a los aymaras bolivianos porque saben trabajar y lo que el dueño le va a decir lo va a cumplir fielmente. Además, como ellos pueden venir con carnet solamente, pueden estar 90 días aquí en Chile, pero con ese documento no puede trabajar. Pero trabajan igual porque los parceleros ya los conocen o entre ellos se recomiendan. Hubo un tiempo que de Investigaciones [policía encargada del control de extranjeros] salían más seguido a controlar, entraban a las parcelas. Pero tengo entendido que ha habido reclamos de parte de los parceleros. Los parceleros decían: 'Pero si no tenemos gente chilena que quiera raimar, la gente chilena que quiere raimar nos pide más caro y además quieren trabajar ocho horas nada más. En cambio, el peruano, el boliviano a las siete de la mañana ya está encaramado en los olivos, nosotros necesitamos sacar la cosecha pronto, si es en una semana mejor (aymara, hombre adulto, urbano).

Los inmigrantes extranjeros indígenas al norte de Chile mayoritariamente llegan a los centros urbanos y se ocupan con empleadores no indígenas. Es común que las mujeres se empleen en casas particulares para realizar servicios domésticos; otras veces se ubican como asistentes de comercio o como obreras en plantas de empacado. Los hombres se hacen presentes principalmente en el área de la construcción y, en general, en la contratación de mano de obra no calificada. En el sector de preparación y expendio de alimentos y bebidas también su presencia es visible. La informalidad del empleo y la ilegalidad parecen ser la tónica más común. Son vistos y tratados como extranjeros pobres y necesitados de trabajo provenientes de países vecinos. Sus posibles antecedentes indígenas (nacimiento en zonas indígenas, conocimiento del quechua o el aymara, influencia de estas lenguas en su desempeño con el castellano) quedan usualmente cubiertos por el manto de la extranjeridad.

\subsection{Los barrios, la vivienda y la experiencia aymara urbana}

Alrededor de tres cuartas partes de los aymaras mantiene residencia urbana. Esta mayoritaria presencia urbana es el resultado de un prolongado proceso de emigraciones con varios ciclos, pulsos y características zonales. Las migraciones más antiguas a Iquique o Arica se relacionan con crisis de articulación campesina a la economía regional, unidas a factores de atracción (Puerto Libre e industrialización de Arica, fomento pesquero en Iquique). Son notorias ya en la década de 1950 y afectan sobre todo a la precordillera andina de Tarapacá y Arica. Posteriormente, el flujo migratorio se mantiene, con una importante activación desde la década de 1980 cuando los campesinos de la alta cordillera andina empiezan a fluir hacia los puertos, los pueblos del desierto y las áreas agrícolas inmediatas a Arica. La residencia urbana aymara se concentra en barrios pobres surgidos de loteos de sitios habitacionales para autoconstrucción (décadas de 1960 y 1970), en soluciones habitacionales resultantes de "tomas" de terrenos fiscales en las periferias urbanas o, como ha sido común durante las últimas tres décadas, mediante adquisición de viviendas básicas a través de planes gubernamentales de subsidio para sectores pobres. En estas áreas de residencia urbana converge también población no indígena de la región o proveniente de otras partes del país, además de descendientes de aymaras, quechuas bolivianos, afrolatinos y algunas familias mapuches inmigrantes.

Si bien pueden advertirse sectores urbanos de Iquique, Alto Hospicio, Pozo Almonte, PicaMatilla o Arica con mayor concentración aymara, no corresponde hablar de fenómenos de segregación residencial sobre bases étnicas, sino que más bien de clase. Y, por tanto, tampoco de guetos 
étnicos ${ }^{30}$. Por lo tanto, la interacción barrial no es sino marginalmente intraétnica. Podría calificarse, en cambio, como prevalentemente interétnica. Sin embargo, hay dos fenómenos que atenúan bastante esta última calificación. Primero, existiría poca interacción barrial en general. Es decir, los hogares aymaras y no aymaras por lo general no construyen redes de conocimiento, confianza y amistad en la vecindad inmediata, especialmente si se trata, como en la mayoría de los casos, de barrios de reciente formación surgidos de la expansión urbana de las últimas décadas. En barrios antiguos la situación posiblemente sea algo diferente, ya que con el paso de los años los de "la cuadra" terminan por conocerse, llevan adelante alguna iniciativa común, integran una organización de vecinos, se construyen algunas relaciones individuales entre mujeres o jóvenes, convergen sobre mismos almacenes, etc. Segundo, la información reunida sugiere que las redes sociales más activas de los aymaras urbanos son con otros aymaras, rurales y urbanos, en particular con parientes, más que con otros grupos de población o los vecindarios. Por cierto, esto es algo especialmente verdadero para la primera generación de emigrados y progresivamente menos para los nacidos en la ciudad, de segunda o tercera generación. Puntualicemos que los hogares aymaras urbanos seguirían en su mayoría encabezados por inmigrantes directos.

La etnificación de las relaciones entre aymaras y no aymaras en los barrios de las ciudades nortinas se encuentra, entonces, sujeta a condiciones que la hacen algo excepcional más que la norma. Exige que se den interacciones entre vecinos en las cuales pueda darse reconocimiento, pero esas interacciones serían poco frecuentes y, cuando se dan, no habría motivos inmediatos para que unos se planteen como aymaras y los demás no. Debe recordarse que los aymaras en las ciudades consideraban que no era conveniente demostrarse como inmigrante del "interior", dado que se exponían a ser objeto de denostaciones al apreciárseles como "indios" y/o bolivianos. Es posible que esta reserva a mostrarse como indígena se haya hoy atenuado, a medida que los cambios de signo desde "indio" a "aymara" se incorporan en las mentes indígenas y no indígenas. Como sea el caso, con el paso del tiempo los hogares de calles, pasajes o cuadras de un barrio se "conocen" (se han recíprocamente identificado y tipificado social o, para lo que aquí interesa, étnicamente), aunque no siempre exista alguna interacción directa. De esta manera, con ocasión de algún problema o detalle de convivencia (pendencias entre niños en la calle, ruidos molestos, dificultades con animales domésticos) pueden surgir controversias, discusiones, reclamos o acusaciones de uno u otro lado y activarse la cara oscura y racista de las representaciones acerca del "indio", el extranjero y el "traficante" nortino. De todos modos, también sabemos de activos dirigentes barriales aymaras apreciados por sus vecinos y de quienes se conocen sus orígenes culturales, así como experiencias de hogares con convivencias de barrio respetuosas y llevaderas.

La residencia urbana obliga a los hogares aymaras a proveerse de servicios básicos, la búsqueda de trabajo e ingresos y resolver necesidades de salud y educación. En estos empeños, se les observa como activos gestionadores para la obtención de beneficios y subsidios provistos por la red social de apoyo a los sectores socioeconómicos más vulnerables, y de ayuda directa a la pobreza extrema. Tanto las oficinas públicas como otros grupos que demandan ayuda social perciben la concurrencia aymara y ello no es objeto de objeciones. Con una excepción: suele cuestionárseles, a veces directamente, que acudan en búsqueda de ayuda estatal en circunstancias de que poseen bienes e ingresos que los dejan fuera de ese derecho según las normativas vigentes. La crítica es que buscarían burlar el sistema de solidaridad público ocultando esas pertenencias y con ello restando posibilidades a personas que sí necesitan auxilio. Esto les parece a sus críticos que representaría un típico rasgo de personalidad aymara determinado culturalmente, junto con la propensión al ahorro y a limitar el gasto. Se naturaliza así algo que de ser extendido no es más que una realidad social.

Uno de los motivos aymaras para la emigración a áreas urbanas es entregar a los hijos educación de mejor calidad y así aspirar a su profesionalización, de tal manera que puedan alcanzar una movilidad social que les permita trabajo e ingresos mejores y más estables y acceso a servicios urbanos apreciados como facilitadores de la vida. La estrategia de doble residencia rural y urbana para las familias que mantienen actividades agropecuarias tiene como uno de sus principales argumentos la necesidad de proporcionar vivienda a los hijos en edad escolar o que están en etapa de estudios técnicos y universitarios. La demanda masiva de becas escolares indígenas para estudios en zonas urbanas forma parte del proceso. 
En la misma universidad tú ves harta gente [aymara], gente de muy baja condición tratando de estudiar... Hijos de agricultores, pagan su matrícula y estudian en la U[niversidad], en el colegio (aymara, hombre adulto, rural).

Yo diría que ha aumentado [el número de indígenas en la universidad]. Donde yo he tenido más alumnos indígenas [es] en las ingenierías, ingeniería comercial, ingeniería en sistemas (...), son matemáticos... Ahí yo he visto más alumnos porque yo he hecho clases en esas ingenierías (no aymara, mujer adulta, urbana).

Sin embargo, un número importante de jóvenes desertan de la enseñanza media o no prosigue con estudios técnicos o profesionales universitarios. Embarazos adolescentes, formación de parejas jóvenes, dificultades económicas de las familias, fracaso en los estudios, motivación de salir luego a trabajar y ganar ingresos frenan para muchos estos empeños.

En la educación primaria, media, técnico profesional y universitaria los aymaras tienen una presencia regional significativa. Ella se concentra en los establecimientos escolares de las áreas residenciales andinas y en los centros de formación y universidades regionales. Adultos que hace unas décadas realizaron estudios en liceos y centros de formación técnica regionales revelan casi sin excepción que fueron objeto de acoso y abusos por su condición indígena ("indio", "paisano", "llamo") y supuestamente extranjera ("boliviano", "cholo"). Aunque normalmente intentaron ocultar su proveniencia desde pueblos y comunidades de la zona interior, su aspecto, la variación dialectal en el empleo del castellano, conductas más tímidas y reservadas, las limitaciones educativas de base que traían, atrajeron usualmente la atención de otros alumnos que activaron sobre ellos la persistente ideología del "indio".

La tónica común de respuesta ante estos hechos fue pasiva y de supuesta indiferencia. En el presente tales conductas no han terminado, pero sí disminuido en frecuencia y quienes las realizan son cada vez menos jóvenes. Una novedad es que estas conductas empiezan a recibir una abierta reprobación y sanciones morales explícitas por parte de otros jóvenes no indígenas, a la vez que mayor atención de docentes y la administración de escuelas y liceos. También es cierto que las tomas de posición étnica proveen una autoridad cultural a los jóvenes afectados desde la cual responder activamente al prejuicio y los tratos vejatorios. Pero no todos o no siempre acuden a ello ${ }^{31}$.

\subsection{Parejas, vida familiar y redes sociales interétnicas}

Las relaciones de pareja, los matrimonios, hogares y familias con composición interétnica están aumentando rápidamente en la sociedad aymara urbana. En la rural también, pero principalmente entre integrantes de familias que se consideran hoy aymaras y otras que no, aunque tengan filiaciones culturales andinas comunes. En el pasado fueron una excepción porque los de "afuera" residentes en áreas andinas eran muy pocos: algún policía o el profesor de la escuela local que se emparejaban con mujeres del poblado. Por lo demás, la propia noción de matrimonio interétnico es confusa cuando se aplica a periodos previos a la etnificación de los últimos años.

Los espacios escolares (aulas de liceos o universidades) y los de esparcimiento y diversión juveniles (deportivos, musicales, grupos de amistad) proveen hoy pertenencia a grupos y redes que están en la base de sociabilidades progresivamente más interétnicas de los jóvenes andinos urbanos. Sus consecuencias sociológicas son mucho más importantes que las que pueden entregar las relaciones de vecindad. Por su parte, el parentesco, la comunalidad y las amistades familiares entre aymaras proporcionan la pertenencia a los grupos y las redes sociales intraétnicas. En las etapas siguientes a la adolescencia, los espacios de trabajo entregan nuevas posibilidades de formación de relaciones interétnicas de amistad, compañerismo o emparejamiento, como también el retorno a los grupos y redes exclusiva o principalmente étnicas. Los testimonios siguientes describen una variedad de experiencias personales:

Yo siempre tuve pololos no indígenas, yo por lo menos. [Con mis hermanas] participábamos en lo que era la agrupación indígena; teníamos los ideales de vida indígena propiamente tal. O sea, era una búsqueda para encontrar, para identificarse, para completar la identidad que tienes, porque en el transcurso uno sufre mucha discriminación, bastante por lo menos en esos tiempos. Y lo que no te debilita te fortalece. Entonces, en algún minuto la idea era eso. $\mathrm{Y}$ ahí uno empieza 
a frecuentar espacios más aymaras y todo. Pero yo nunca tuve un pololo aymara, por casualidades de la vida, por elección, no sé (aymara, mujer adulta, urbana).

Otro caso, esta vez de una pareja interétnica:

Lo conocí viajando para el interior... Él es de Iquique, pero lo bonito de él es que, como trabaja con los pueblos de arriba, comprende mucho la cultura, entonces ahí nos complementamos harto, no tenemos ningún problema. Me apoya en todo y comprende si hay alguna manera de ser mía que viene por herencia, por genes. Comprende porque ha trabajado con aymaras... y como yo soy dirigente también y lucho por algo, por un ideal (aymara, mujer adulta, rural).

Mientras más orientadas están las familias aymaras hacia las actividades agrícolas, el comercio y transporte de productos agropecuarios, mayores probabilidades hay que las pertenencias de grupo y las redes sociales se concentren en lo aymara. Con mayor probabilidad también los jóvenes aymaras tenderán a quedar incorporados a la órbita de estas actividades y a relaciones intraétnicas. Si la posición económica de estas familias es precaria, las posibilidades de inclusión se hacen correlativamente menos plausibles y las necesidades de recurrir al asalariamiento de sus miembros aumenta. Esta realidad se daría con más frecuencia en las familias de emigración reciente, en especial desde la alta cordillera andina de Parinacota y Tarapacá.

Las familias de emigración más antigua con una, dos y a veces tres generaciones de nacidos en las ciudades seguirían patrones étnicamente más diversificados de relaciones. Los extremos corresponderían, de una parte, a fuertes redes y participación en grupos andinos de origen comunitario y, en el otro, a familias andinas que han realizado una completa dilución en la sociedad regional, no reconociendo o no siendo socialmente significativos los orígenes andinos, incluido en esto la renuencia a considerarse indígena. Muchos casos posiblemente se sitúan en una posición intermedia de este continuo.

Mi esposa no es aymara. (...) Yo vengo de un pueblo que se llama Belén, en el cual mi abuelo es de allá, mi hermana de allá. Mi papá nació en Codpa. Tú sabes que a veces uno, cómo te puedo decir, por trabajo tiene otros roces sociales. Yo trabajé en el banco muchos años (aymara, hombre adulto, urbano).

\section{Otro testimonio:}

Por ejemplo, mi nieta: rubiecita, bonita, grandota. Si yo miro a mi nieto: flaco, alto. Apellido: Muñoz. Esos son mis nietos, hoy día no tienen rasgos andinos. Y eso pasa en Belén, lo mismo: los primos se casaron con una blanca y, por ende, los hijos son blancos, y sus hijos todos son rubios (aymara, hombre adulto, urbano).

Los ingresos de las nuevas generaciones aymaras se basan progresivamente más en el trabajo asalariado. Ello obedece a que la oferta de empleo remunerado se ha incrementado en las regiones mineras del norte; en particular, por el dinamismo generado con la expansión de la gran minería cuprífera durante los últimos 20 años. Por otra parte, la economía aymara rural y urbana tiene límites estrechos para la incorporación de nuevos contingentes de personas; más aun si se presenta la alternativa de la incorporación de trabajadores indígenas extranjeros. Por cierto, los jóvenes aymaras pueden empezar sus vidas postescolarización y estudios técnicos o universitarios en las redes de trabajo familiares y parentales, para luego dirigirse al trabajo asalariado cuando se abren oportunidades de empleo. De cualquier modo, las actividades por cuenta propia y las redes familiares y de parentesco suelen ser un refugio ante crisis de empleo en el mercado de trabajo de las regiones nortinas.

En suma, tanto a partir de las redes sociales construidas desde la experiencia escolar o de formación técnica y universitaria, como de aquellas que se constituyen en los espacios laborales, los emparejamientos y la formación de familias interétnicas son una realidad aymara extendida y frecuente. Al respecto cabe precisar varias situaciones relativas a la estabilidad de estos vínculos. Las vivencias de "andar" juntos, "pololeo" y noviazgo arrancan durante la etapa de estudiantes y suele darse cierta rotación de experiencias intra e interétnicas. Ya más adelante, las relaciones de emparejamiento pueden dar origen a convivencia y, a menudo, al nacimiento de algún hijo. El término de la convivencia y el abandono paterno de algún o algunos 
hijos nacidos en ese periodo es común, ya se trate de parejas aymaras como de aquellas en que uno de los cónyuges no es indígena. Las cuestiones relativas a los compromisos de crianza y su financiamiento suele dar origen a agudos conflictos entre los padres separados. Es común la judicialización de tales desacuerdos, destacándose su frecuencia por relación a lo que ocurre en otras regiones indígenas con parecidas realidades de base.

Cuando las parejas interétnicas permanecen, se plantea la necesidad de arreglos de convivencia entre quienes, por sus orígenes familiares y antecedentes étnicos, mantienen actitudes y desarrollan prácticas distintas en una variedad de asuntos. Un aspecto importante de estas acomodaciones es la relativa a los compromisos y participación con las respectivas familias de proveniencias y sus parentelas. Mientras entre los no indígenas parece estar más presente la motivación por una cierta distancia con los hogares de los padres, entre los aymaras decisiones de este tipo parecen menos fáciles. Las mujeres no aymaras, urbanas por definición, se adaptan mal a la vida campesina en la montaña, a la altura, a la precariedad de las viviendas en el campo y a la falta de servicios. Algunos testimonios muestran a estas mujeres buscando hacer prevalecer sus fórmulas urbanas de vida y los maridos indígenas acomodándose a ellas. A su vez, mujeres aymaras que tienen cónyuges no aymaras tenderían a establecer otros arreglos. Como estas pueden sentirse comprometidas con sus familias de proveniencia, frecuentemente presionan a sus parejas no indígenas para que participen de la vida social aymara (reuniones festivas, asistencia a fiestas religiosas). Estos pueden ceder frente a los compromisos familiares de la esposa. Habría también arreglos en que una de las partes tiende a sustraerse de compromisos parentales o culturales y la otra se involucra más en lo suyo, o fórmulas más equilibradas en que mutuamente se acompañan en los compromisos de cada quien, o soluciones más libres de concentrarse en la relación de pareja y limitar los compromisos hacia afuera.

\section{Conclusiones}

Partimos preguntándonos en qué medida las relaciones entre las personas y grupos en la sociedad chilena se han etnificado durante las últimas décadas o, lo que es lo mismo, hacen participar en sus interacciones estipulaciones de etnicidad, cuando al menos una de las partes se considera integrante de un pueblo originario o etnia indígena. La pregunta es pertinente si se considera que movimientos sociales y dirigentes han demandado insistentemente ser reconocidos y tratados como representantes y partícipes de pueblos originarios o, más genéricamente dicho, etnias indígenas. Y con ello ganar o, al menos, avanzar hacia una sociedad culturalmente más pluralista. Una política pública de acción afirmativa hacia los pueblos indígenas o pueblos originarios ha sido puesta en marcha en las últimas dos décadas y, según todo lo conocido, ha tenido repercusiones (aunque de seguro no todas las buscadas y no tan solo las imaginadas). O si, en caso de haber ocurrido, ello no es otra cosa que la continuidad de las relaciones formadas históricamente hace mucho más tiempo sobre la base de esquemas de identidad / alteridad, de los cuales los étnicos actuales serían una simple continuidad o versión de lo mismo adaptada a los tiempos. El caso aymara resulta de gran interés frente a estas interrogantes porque, con arreglo a lo conocido, los fenómenos de surgimiento étnico son recientes, y están teniendo consecuencias importantes de cambio en la subjetividad y las relaciones sociales en que están presentes indígenas del extremo norte del país.

Abrirse paso en búsqueda de respuestas a estas preguntas supone al mismo tiempo explicitar una perspectiva de análisis y confrontar algunas visiones desde lo cual tratar la información reunida en los estudios que originan este escrito. Un primer problema se refiere a la cultura, su naturalización e historización. Como dimos a entender, no está en discusión la existencia de culturas históricas con antecedentes lingüísticos, religiosos, institucionales, territorialidades y prácticas sociales. Pero de ello no se deriva que lo cultural en los pueblos originarios de hoy pueda ser reducido a esas culturas históricas, ya que en los hechos sus miembros, más allá de la tipificación y deslinde de signos, símbolos y prácticas culturales definidos como genuinamente propios que se ha operado en los últimos tiempos, movilizan en su vida social repertorios muy variados de significaciones, relaciones y prácticas sociales. Y ello a pesar de que la mayoría de los que se identifican como miembro de un pueblo originario andino considera poseer y portar un núcleo o esencia cultural que lo entronca con los orígenes. Muchas veces piensan de sí mismos, también, que se conducen con arreglo a ese núcleo originario o tradicional que portan y que ello marca e incide sobre su conducta. La clásica concepción antropológica 
de las culturas como totalidades sociales encaja bastante bien con estas ideas esencializadoras (si acaso no contribuyeron a crearlas).

Sin embargo, al tomar el camino de esa Antropología y el de las ideologías étnicas que complementa, nos encontramos con una redundancia y un absurdo. Aquella se presenta al delimitar, externamente, según una mirada objetivista y estructural, quien es o no indígena y después, simplemente -con esto entramos al absurdo-, describir cualquier tipo de relación que los así definidos realicen con otros no indígenas u otros originarios, porque todas serían interétnicas. De ahí que resulte indispensable separar las nociones de cultura de las de etnicidad.

Por lo demás, en esos términos caemos en la limitación empirista de contentarse con un conocimiento basado en las categorías del sentido común acerca de cuál es la cultura indígena, qué elementos la caracterizan, sus esencias eventualmente entroncadas en los genes, etc.Y llegamos a una historicidad que concibe la cultura indígena en un "presente continuo" (Vergara et al. 2013:354). La condición de pueblo originario o etnia tiene por supuesto la existencia de una cultura distintiva y propia que constituye el fundamento de su asunción de identidad / diferencia y demandas sociales. Esa cultura participa de la larga duración, pero la historia del grupo es tratada como la evaluación de cuán lejos o no han sido llevados por la acción de sociedades dominantes respecto de un núcleo cultural, cuando no original al menos sí congruente con esos orígenes. De aquí proviene la común naturalización de la historia y la cultura, en el sentido de que cada cambio en éstas es apreciado como un alejamiento, mayor o menor, desde ese centro en una fuga perpetua. Y los factores responsables son siempre las influencias e imposiciones externas, en su mayor parte indeseables. Se tiende entonces a concebir la sociedad y la historia de los pueblos originarios como carentes de vitalidad, de capacidad y voluntad de cambio, porque cuando ellos se producen es siempre como efecto de fuerzas externas. Sí habría, en cambio, voluntad de persistir, cuestión que es atribuida a un inconmovible empeño de resistencia. Por esto es que en las demandas y los programas de organizaciones, $y$ de algunas agencias públicas, sean tan comunes nociones como las de recuperación cultural, patrimonio cultural, cultura genuina, la vida organizada por valores culturales fundamentales, entre otras.

En el punto mencionado topamos con otra dificultad, la que concibe, o por vía de los hechos produce, un conocimiento que podemos calificar como normativo, de voluntarismo político o de lo políticamente correcto, que pone el énfasis en lo que la realidad social debería ser, en este caso las relaciones interétnicas, y en cuánto ella se aleja o se acerca a ese estado utópico deseado (relaciones horizontales, reconocimiento, prácticas sensibles a los derechos), y no a lo que la realidad social es en un determinado momento y lugar.

Creemos que las dificultades que se alzan para el conocimiento de las relaciones interétnicas pueden disminuirse al incorporar una perspectiva centrada en los actores, su experiencia, subjetividad y situación social. Es decir, enfatizando en primer lugar el análisis de quienes (personas y grupos) y desde qué posiciones (condición de clase, de género, económica, socio o sociocultural) e inscripciones sociales (como campesino, habitante rural o "andino", "aymara", residente urbano, ciudadano) o combinaciones de ello se interactúa. Posiciones e inscripciones se acompañan de identificaciones, pertenencias y alteridades. Unas y otras permiten, hasta cierto punto, producir estrategias de identidad y alteridad, las étnicas entre otras. Es decir, desempeños o desenvolvimientos, a veces conscientes y calculados, otras muchas como hábitos incorporados a la vida social y actuados "naturalmente". Complementariamente, un enfoque centrado en los actores sociales indígenas no puede prescindir del hecho que se encuentran situados en condiciones sociohistóricas y estructuras sociales y de poder que ponen parámetros y límites a su accionar, circunscribiendo los cursos y posibilidades de acción interétnica. Como queda bien de manifiesto del hecho que no cualquier persona puede asumir una pertenencia indígena, como tampoco ser reconocida como tal; y no en cualquier lugar o circunstancia ello puede ser pertinente o aceptado, si es que no rechazado. Transformaciones relevantes del contexto, unido al procesamiento interno de esos cambios, pueden dar origen a surgimientos rápidos y drásticos, como creemos que ha ocurrido en las últimas dos décadas con el sistema de identidades y alteridades de los pueblos originarios andinos del norte de Chile, el aymara en destacado lugar. Por cierto, con el concurso de elementos previos de la historia sociocultural andina: la construcción de un sentido de lo "aymara" como pueblo originario o etnia se hizo sobre la base de la noción de "indio", en los términos que se señalaron, partícipe de un arreglo o esquema de categorías de identidad y alteridad modernos al que los nuevos aires multiculturales 
están reemplazando. Bajo consideraciones como las expuestas y aplicadas al caso aymara es que podemos conocer en sus detalles y variedad el lugar de la etnicidad en las relaciones sociales que efectivamente se están produciendo, dada una historia y encuadre sistémico actual de lo andino.

¿Y qué ha estado ocurriendo en las regiones aymaras con la etnicidad y las relaciones interétnicas que se han ido estableciendo durante los últimos lustros? Quisiéramos consignar algunos fenómenos analizados y discutidos más arriba. El primero de ellos es la transformación del sistema de identidades y pertenencias colectivas. La categoría de "aymara", a la vez que reemplaza a la estigmatizante noción de "indio", cubre de signos positivos al nombre étnico (los principales: aboriginalidad, especificidad cultural, afirmación, igualdad, derechos). Y, con ello, hace posible las relaciones interétnicas; las previas, según hemos dado a entender, tenían una base sociocultural, pero no eran, precisamente, interétnicas. Pero esa otra categoría, la de "indio", no ha desaparecido, por mucho que haya quedado reposicionada en un cuadro semántico y de etiquetas sociopolíticas distintas, debido a que todavía participa de estereotipos persistentes, a la vez que integra la formación de nuevos prejuicios. En efecto, las interacciones en espacios laborales, educacionales o poblacionales pueden, a veces, adquirir el carácter de controversias, conflictos, agravios e incluso actos discriminatorios y, en esos casos, interpelaciones como las de "indio" (atrasado), "paitoco" (rústico), "llamo" (forma de animalización) o "boliviano" (extranjero, despectivamente dicho) pueden hacer su aparición. Con mucha más frecuencia, no obstante, las respuestas son inmediatas y directas según una variedad de registros. Así también, los prejuicios de "traficante" (de drogas) y "extranjero" (de segunda categoría) se presentan activos, lo cual pone en evidencia que a pesar de los cambios políticos y culturales ocurridos en los aymaras y con los demás habitantes de la región, sus efectos sobre el término o la contracción de la violencia simbólica, los estereotipos y prejuicios hacia los indígenas son, por decir lo menos, bastante matizados.

Un gran número de personas hoy se consideran aymara en el norte de Chile, aunque no están todos los que podrían esgrimir una construcción biográfica y pertenencias grupales que los acreditaría como integrantes de este pueblo originario. Y para muchos de aquellos ese integrar no es solo nominal, o relativo a algún beneficio material particular, sino que también expresivo, poniendo de manifiesto un cierto orgullo, destacando valores culturales, estipulando derechos, asentando la pertenencia étnica en una utopía social, etc. Y para otros tantos es un vínculo activo, como cuando se integra organizaciones "aymaras", se es partícipe de demandas, se acogen a medidas de afirmación provistas por el Estado, o actúan con otros como "aymara" y, en esa medida, realizan interacciones con sentido étnico. En todo esto, desde luego que ha tenido importancia la política de acción afirmativa desplegada desde la década de 1990 con la Ley Indígena No 19.253 y su antesala, el actuar de las propias organizaciones y los medios de comunicación, en contraste con el pasado inmediato que culmina a fines de la década de 1980 .

Como hemos destacado, algunas interacciones y relaciones de las que participan los aymaras cabe calificarlas de interétnicas. Asimismo, muchas menos de las que podrían plantearse así se procesan con sentido de etnicidad. Esto es así debido a que la aymara no puede considerarse una región de relaciones interétnicas históricas, sino que una sujeta a construcción social reciente. Por lo demás, recordando la mayoritaria condición urbana aymara, el contenido de las interacciones es diversificado y las posiciones de sujeto en cada circunstancia soportan flexibilidad y variedad. En cambio, algunas relaciones especializadas, como las que se dan desde agentes públicos aymaras, o viceversa, pueden con más frecuencia, pero no siempre, formularse de manera etnificada, precisamente porque una condición de la relación es su etnificación. Ámbitos sociales que suponen interacciones más o menos continuas o frecuentes, como los laborales, educacionales o de vida poblacional, pueden también adquirir adjetivaciones e implicación étnica por parte de personas indígenas. En otros, como en las relaciones de pareja, se suscita construcción de arreglos y acuerdos, a veces laboriosos, en que lo étnico e interétnico puede formar parte de ello o decidirse su anulación.

Agradecimientos: En la fase de terreno y sistematización primaria de información reunida para este estudio se contó con la ayuda de las antropólogas Ana Ancapi y Lenina Barrios, a quienes agradecemos su aporte. Agradecemos también el interés en este trabajo por parte de dos lectores anónimos, quienes llevaron a efecto una revisión cuidadosa y realizaron observaciones, críticas y recomendaciones que contribuyen a dirigir las aclaraciones y cambios que se encuentran en la presente versión. Algunos de esos 
alcances sobrepasan cualquier posibilidad de ser debidamente atendidos, dada la doble circunstancia de que por una parte se nos pidió reducir el tamaño del artículo y, por otra, ampliarlo con testimonios, aclaraciones y comentarios. Constreñidos de tal modo, procuramos un equilibrio entre satisfacer los requerimientos que se nos hacen, a la vez que limitar la extensión del trabajo. Por otra parte, nos satisface el conjunto de temas que evoca y las preguntas que suscita una materia descuidada y frecuentemente dada por sabida de la vida social contemporánea de los pueblos originarios de Chile. Se agradece también al Convenio de Desempeño Universidad de Tarapacá y Ministerio de Educación Pública.

\section{Referencias Citadas}

Assies, W., G. van der Haar y A. Hoekema (eds.) 2000. The Challenge of Diversity; Indigenous Peoples and Reform of the Estate in Latin America. Thela Thesis, Amsterdam.

Bengoa, J. 1999. Historia de un Conflicto. El Estado y los Mapuches en el Siglo XX. Editorial Planeta, Santiago.

- _ - 2 2000. La Emergencia Étnica en América Latina. Editorial Fondo de Cultura Económica, Santiago.

Choque, C. 2009. Divergencias y antagonismos del movimiento social indígena en la Región de Arica y Parinacota (1965-1985). Confluenze. Rivista di studi iberoamericani 1(2):267-289.

Comisión de Verdad Histórica y Nuevo Trato 2008. Informe de la Comisión de Verdad Histórica y Nuevo Trato con los Pueblos Indígenas. Editorial Pehuén, Santiago.

Comaroff, J. y J. Comaroff 1992. Ethnography and the Historical Imagination. Westview Press, Boulder.

_ _ _ 2011. Etnicidad S.A., Katz, Buenos Aires.

Fischer, S. 2005. Islands at the End of the World. The Turbulent History of Easter Island. Reaktion Books, Londres.

Foerster, R. y S. Montecino 1988. Organizaciones, Líderes y Contiendas Mapuches (1900-1970). Ediciones CEM, Santiago.

Fuenzalida, F. 1971. Poder, etnia y estratificación social en el Perú rural. En Perú, Hoy, editado por F. Fuenzalida, pp. 8-85. Editorial S. XXI, México.

Geertz, C. 1995 [1973]. La Interpretación de las Culturas. Gedisa, Barcelona.

Giménez, G. 2009. Cultura, identidad y memoria. Materiales para una sociología de los procesos culturales en las franjas fronterizas. Frontera Norte XXI (41):7-32.

González, H. 1996a. Características de la Migración CampoCiudad entre los Aymaras del Norte de Chile. Documentos de Trabajo, Corporación Norte Grande, Arica.

_ _ _ 1996b. Los Migrantes Aymaras en la Ciudad: Acceso a Educación, Vivienda y Salud. Documentos de Trabajo, Corporación Norte Grande, Arica.

_ _ _ 1997a. La inserción económica de los migrantes aymara en la ciudad: el trabajo como empresa familiar y la reproducción cultural. Actas Segundo Congreso Chileno de Antropología, vol. 1, pp. 315-324. Colegio de Antropólogos de Chile, Santiago.

. _ _ 1997b. Economía y uso del espacio en la sociedad aymara actual. Actas Segundo Congreso Chileno de Antropología, vol. 2, pp. 567-579. Colegio de Antropólogos de Chile, Santiago.

Grimson, A. 2011. Los Límites de la Cultura, Crítica de las Teorías de la Identidad. Siglo XXI Editores, Buenos Aires.
Gros, Ch. 2000. Políticas de la Etnicidad: Identidad, Poder y Modernidad. Instituto Colombiano de Antropología e Historia, Bogotá.

Gundermann, H. 2000. Las organizaciones étnicas y el discurso de la identidad en el norte de Chile, 1980-2000. Estudios Atacameños 19:75-91.

_. _ 2003. Las poblaciones indígenas andinas de Chile y la experiencia de la ciudadanía. En Mapuches y Aymaras. El Debate en Torno al Reconocimiento y los Derechos Ciudadanos, editado por H. Gundermann, R. Foerster y J.I. Vergara, pp. 19-104. Universidad de Chile, Predes, Ril Editores, Santiago.

Instituto Nacional de Estadísticas (INE) - Orígenes 2005. Estadísticas Sociales de los Pueblos Indígenas de Chile, Censo 2002. INE - Orígenes, Santiago.

Laclau, E. 1985.New social movements and the plurality of the social. Latin American Studies 29:27-42.

Lavanchy, J. 2004. Etnogremialismo mapuche: notas e hipótesis sobre la organización Centros Culturales Mapuches de Chile/ Asociación Gremial de Pequeños Agricultores y Artesanos Ad-Mapu. Documento del Seminario de Doctorado en Historia, Escuela de Postgrado de la Facultad de Filosofía y Humanidades, Universidad de Chile, Santiago. Manuscrito en poder de los autores.

Le Bonniec, F. 2009. La Fabrication des Territoires Mapuche au Chili de 1883 á nos Jours. Communautés, Cannaissances et Etat. Tesis Doctoral, Ecole des Hautes Etudes en Sciences Sociales, Paris.

Mallon, F. 2004. La Sangre del Copihue. La Comunidad Mapuche de Nicolás Aylío y el Estado Chileno (1906-2001). Lom Ediciones, Santiago.

Marimán, P., S. Caniuqueo, J. Millalén y R. Levil 2007. j...Escucha, Winka...! Cuatro Ensayos de Historia Nacional Mapuche y un Epílogo sobre el Futuro. Lom Ediciones, Santiago.

Menard, A. y J. Pavez 2005. El Congreso Araucano: Ley, raza y escritura en la política mapuche. Revista Política 44:211-232.

Méndez, C. 2011. De indio a serrano: nociones de raza y geografía en el Perú (siglos XVIII-XXI). Histórica XXXV(1):53-102.

Pfaff-Czarnecka, J. 2011. From ‘identity' to 'belonging' in social research: plurality, social boundaries, and the politics of the self. En Ethnicity, Citizenship and Belonging. Practices, Theory and Spatial Dimensions, editado por S. Albiez, N. Castro, L. Jüssen y E. Youkhana, pp. 199-219. Iberoamericana-Vuervert, Madrid-Frankfurt.

Programa de las Naciones Unidas para el Desarrollo (PNUD) 2009. La Manera de Hacer las Cosas. Informe de Desarrollo Humano en Chile. PNUD, Santiago.

Porteaus, D. 1981. The Modernization of Easter Island.University of Victoria, Western Geographical Series vol.19, Canada. 
Portes, A. y L. JENSEN. 1987. What's an ethnic enclave? The case for conceptual clarity. American Sociological Review $52: 768-771$

Rasse, A. y F. Sabatini 2013. Alteridad étnica y socioeconómica en las ciudades chilenas. En Pueblos originarios y sociedad nacional en Chile: la interculturalidad en las prácticas sociales, editado por J. Durston, pp. 183-209. CEPAL, Santiago.

Skuban, W. 2007. Lines in the Sand: Nationalism and Identity on the Peruvian-Chilean Frontier. University of New México Press, Alburquerque.

Van Cott, D.L.2000. The Friendly Liquidation of the Past; the Politics of Diversity in Latin America. The University of Pittsburgh Press, Pittsburgh.

Van den Berghe, P. 1975. Ethnicity and Class in Highland Peru. En Ethnicity and Resource Competition in Plural Societies, editado por L. Despres, pp. 71-85.Mouton, Netherlands.
Van den Berghe, P. y G. Primov1977. Inequality in the Peruvian Andes: Class and Ethnicity in Cusco. University of Missouri Press, Missouri.

Vergara, J.I., R. Foerster y H. Gundermann 2005. Instituciones mediadoras, legislación y movimiento indígena: de DASIN a CONADI (1953-1994). Atenea 491:71-85.

Vergara, J.I, H. Gundermann y R. Foerster 2013. Estado, Conflicto Étnico y Cultura. Estudios sobre Pueblos Indígenas en Chile. Serie Qillqa, UCN-UA, San Pedro de Atacama.

Weber, M. 1992 [1922]. Economía y Sociedad. EFCE, México D.F.

Zapata, C. 2004. Atacameños y Aymaras. El desafío de la verdad histórica. Estudios Atacameños 27:169-187.

- - - 2007. Memoria e historia. El proyecto de una identidad colectiva entre los aymaras de Chile. Chungara Revista de Antropología Chilena 39:171-183.

\section{Notas}

1 Trabajo realizado en el proyecto Fondecyt $\mathrm{N}^{\mathrm{o}} 1110246$ "Cultura y procesos étnicos en Chile: la formación del campo de lo cultural indígena" (2011-2014), y del estudio "Relaciones interétnicas en Chile" (2011-2013) del Programa de las Naciones Unidas para el Desarrollo (PNUD), Santiago de Chile.

2 Entre otros posibles de consultar, véase: Bengoa (1999); Fisher (2005); Foerster y Montecino (1988); Gundermann (2003); Le Bonniec (2009); Mallon (2004); Marimán et. al. (2007); Porteaus (1981); más recientemente, Comisión Verdad Histórica y Nuevo Trato con los Pueblos Indígenas (2008); el listado de obras útiles es por cierto más numeroso.

3 Nos limitamos a señalar algunos factores de importancia, entre otros. Para énfasis distintos respecto de la formación de la organización y el movimiento aymara, consúltese Choque (2009:267-289). El caso mapuche es más complejo porque la formulación étnica se realiza sobre la base de una larga historia de organización, liderazgos y representación como grupo, aunque concebido según otras formas discursivas ("raza", "indígena", clase) (Menard y Pavez 2005). Es en la década de 1980 cuando organizaciones mapuches y andinas se rearticulan, en un caso, o se crean, en el otro, tomando ideas desde el indianismo desplegado en el Consejo Indígena Sudamericano (CISA), del Katarismo boliviano, del Consejo Mundial de Pueblos Indígenas, de los movimientos indígenas canadienses o de Laponia y de movimientos etnonacionales de diversos lugares del mundo. Mismas nociones que se van poniendo a tono con realidades, conflictos y demandas preexistentes, particularmente en el caso mapuche. Un momento privilegiado de circulación de ideas en Latinoamérica y Chile se dio con ocasión del Quinto Centenario de la conquista de América (Bengoa 1999; Gundermann 2000; Lavanchy 2004).

4 Para una presentación acerca de las condiciones de su emergencia en Latinoamérica, de lo cual se nutren las ideas y demandas recientes de los pueblos originarios de Chile, consúltese Assies et al. (2000), Bengoa (2000), Gros (2000) y Van Cott (2000).

5 La noción de inscripción de sujeto la tomamos de Laclau (1985).
6 La etnicidad no es sinónimo de cultura, sino más bien una dimensión de ella: "un repertorio [de signos] a través del cual se torna sensible una conciencia colectiva de la similitud cultural" (Comaroff y Comaroff 2011:65; también 1992:49-67).

7 Contribuyen lo suyo, también, agentes y agencias de la sociedad civil como los organismos no gubernamentales, algunas organizaciones políticas y sectores de la iglesia católica. Por el lado del Estado se llevan a cabo mediante un conjunto de acciones, por lo demás bastante generales a Latinoamérica: reformas constitucionales, cambios legislativos, políticas de acción afirmativa, cambios en la institucionalidad pública, formación de una elite profesional y de burócratas indígenas, reconocimientos de autonomías territoriales parciales, programas diversos de educación intercultural bilingüe, etc.

$8 \quad$ El sentido en que ocupamos esta noción se hace explícito en el análisis que desarrollamos más abajo.

9 El significado de estas categorías corresponde, salvo mayores precisiones, con las definiciones antropológicas comunes, convergente con las acepciones que se ocupan en la política étnica oficial en Chile.

10 La definición clásica de Max Weber identifica cuatro formas abstractas de acción social: tradicional (costumbre), conducida por principios y normas culturales; afectiva (emocional, de carácter principalmente irracional guiada por emociones como el amor, odio); racional con arreglo a valores en que, además de perseguirse un fin racional está guiada por principios o normas morales, e instrumental, destinada a conseguir un fin racional (Weber 1992 [1922]).

11 Para una discusión del concepto de pertenencia en relación con los de identificación e identidad, consúltese el trabajo de Pfaff-Czarnecka (2011). Preferimos ocupar la noción de identificación, más que la de identidad, ya que facilita entender estos fenómenos simbólicos y sociales de una manera constructiva y procesual. Esas mismas posibilidades analíticas no se presentan con una noción sustantiva y esencial de identidad colectiva, cultural en este caso.

12 Analíticamente podemos reconocer tres opciones de relación entre adscripciones de identidad y cultura. Primero, 
la identificación y la cultura son coherentes entre sí, particularmente en los núcleos rurales antiguos. Segundo, se participa de elementos de cultura, pero no identificación o sentido de pertenencia étnica. Es el caso de muchas personas de extracción indígena que en Chile han buscado o han sido llevados a asimilarse al resto de la sociedad, pero mantienen ciertas ideas y prácticas que podemos -externamente-- considerar características de un pueblo indígena. Tercero, se tiene adscripción de identidad, pero no se realizan prácticas culturales propias o estas son mínimas; se manejan más bien repertorios culturales diversos, principalmente no indígenas. A veces lo cultural indígena se reduce a gestos simbólicos: una libación a la Pachamama o saludar en lengua mapuche, por ejemplo.

13 Como se habrá advertido, participamos de una concepción de lo cultural como significados socialmente compartidos. Remitimos a una lectura que ha llegado a ser clásica, la de Clifford Geertz (1992 [1973]). De interés es también la noción de configuración cultural presentada por Grimson (2011).

14 Para una presentación de las nociones de cultura, identidad, alteridad y fronteras étnicas, que aquí seguimos en algunos aspectos, consúltese Giménez (2009). Por limitaciones de espacio no es posible extendernos y plantear una discusión circunstanciada de estas categorías. Las acepciones con que empleamos estos términos son razonablemente explícitas a lo largo del texto. Cuando es oportuno introducimos definiciones y referencias a autores y fuentes.

15 Una interpretación acerca de la historia moderna aymara, los procesos culturales y la dinámica de las identidades colectivas, convergente en lo general con lo aquí expuesto, se encuentra en Comisión de Verdad Histórica y Nuevo Trato con los Pueblos Indígenas (2008).

16 Sí es cierto, en cambio, que en la documentación administrativa o en informes de viaje y testimonios de terceros no indígenas aparece a veces la caracterización de lo aymara (y lo atacameño) como raza y, adosado a ello, ideas de inferioridad, atraso o carencia de civilización. Por tanto, con bastante razón un lector de este artículo reclama la ausencia en nuestro análisis del "darwinismo social" que irradió en América Latina, los países andinos y del Cono Sur, considerándolo una etapa intermedia entre el "indio" colonial y la representación moderna del indio como sujeto situado en el rezago civilizatorio. El caso es que en las adscripciones de identidad colectiva de los pueblos originarios andinos esta idea, hasta donde sabemos, no se generalizó, no ganó una real notoriedad, no se transformó en un hecho socialmente significativo, a pesar de estar a veces presente en el discurso de algunas autoridades regionales o en otros agentes públicos o civiles y no ser del todo desconocido para ciertas personas indígenas.

17 Acerca del sistema de relaciones e identidades sociales en el Perú andino de hace algunas décadas, analogable con el que aquí hacemos mención, puede consultarse Fuenzalida (1971); Van den Berghe (1975) y Van den Berghe y Primov (1977).

18 Las intensas emigraciones aymaras a los valles costeros y los puertos del norte del país no originan la conformación moderna de lo étnico. La evidencia disponible no es por ahora suficientemente contundente como para asumir que la noción de "andino", vocablo con el que la población inmigrante indígena empieza a ser conocida (y con arreglo a lo cual da inicio a ensayos de organización supracomunitaria, una de fútbol en particular, llamada "Liga Andina") es una forma de identidad étnica (Choque 2009). Como categoría de descripción es muy explícita respecto de proveniencia geográfica, pero misma a la que se le adosan los atributos del "indio" (marginalidad geográfica, atraso, carencias educativas, pobreza, etc.), y en tal caso carece de ese elemento de prestigio, autoridad y, en definitiva, legitimidad que más recientemente sí logró constituirse alrededor del concepto de "aymara". Representó una exodenominación ambigua y también un concepto en torno al cual aglutinar, ahora internamente, iniciativas de acción colectiva deportivas y económicas. Pero no creemos que ello pueda entenderse, salvo mejor información y análisis, como la transliteración de una identidad étnica. En suma, la asociación entre "indio" y "serrano" en Perú (Méndez 2011) o entre "indio" y "andino" tal como se da en la convivencia de las poblaciones y las plazas de mercado en el norte de Chile, no puede entenderse como el momento del surgimiento de lo étnico; ni allá, ni aquí.

19 Hemos tocado algunos temas pertinentes (Gundermann 2003). Una obra reciente de interés para contextualizar estas relaciones es la de Skuban (2007). A nuestro pesar, no cabe extenderse mucho más realizando una presentación teórica del nacionalismo, la identidad nacional, su relación con otras identidades colectivas y como todo ello se conjuga histórica y antropológicamente en el norte del país. Aunque creemos de indudable importancia y necesidad estudiar tales dimensiones y relaciones, no podemos sino concentrarnos en lo atinente a las relaciones interétnicas contemporáneas.

20 La de "indio" no constituye hoy una identidad de signo positivo, sino más bien un estigma social. Aunque es un ingrediente del sistema de identidades colectivas andinas contemporáneo, no genera identificaciones debido a las valencias negativas que se le asocian.

21 Un estudio que analiza la CONADI en perspectiva histórica es el de Vergara et al. (2005).

22 Un estudio de la formación de la etnicidad aymara durante las décadas de 1980 y 1990 en Gundermann (2000). Puede consultarse también Zapata (2007); Comisión de Verdad Histórica y Nuevo Trato (2008), y Choque (2009).

23 Y en un tono decididamente destemplado: "Me di cuenta de que los mismos paisanos son tan racistas y clasistas y tienen tanto desdén hacia el verdadero indígena como el chileno. Ellos lo cubren desde el nacionalismo diciendo: 'No, es que ese es boliviano o peruano'. Pero en el fondo tienen grabado en la cabeza, por la chilenización que creo que hubo acá, el desdén patriotero del chileno medio, de despreciar al boliviano, al peruano. El mismo aymara, el mismo paisano lo hace. Los supuestos yatiri [oficiantes de prácticas adivinatorias y médicas] también los he escuchado que hacen esas diferencias: 'Tienen que aprovecharnos a nosotros que somos chilenos, y no a esos extranjeros"' (no aymara, hombre adulto, urbano).

24 "En esta zona predominan, respecto de indígenas, las imputaciones por delitos asociados a la ley contra el tráfico de drogas, la ley de drogas, que son una serie de delitos. Como se trata de una zona fronteriza, y en la frontera hay una importante población aymara..." (no aymara, hombre adulto, urbano). 
25 El papel de los medios de comunicación e Internet en estos y otros fenómenos étnicos regionales debe ser reconocido en su importancia. Por desgracia carecemos todavía de buenos estudios sobre la materia.

26 Señalamos la existencia de discusiones y controversias culturales, relativas a memoria histórica, identidad, cultura genuina, legitimidad cultural y derechos culturales. No nos pronunciamos sobre el valor de verdad de los argumentos y contraargumentos que se esgrimen en los discursos sociales que aluden a estos asuntos.

27 El tema de las relaciones intraétnicas entre sujetos ubicados en distintos roles y posiciones de poder (como el del funcionario indígena y el campesino o poblador aymara), sus encuentros y desencuentros, el desarrollo de segmentos diferenciados de aymaras (comerciantes, transportistas, profesionales, intelectuales, figuras políticas locales) y sus relaciones con la gente indígena de la base, es de indudable importancia e interés. En el marco de este artículo apenas tocamos el tema. En esta materia puede ser de interés la consulta de Gundermann (2000); Zapata (2004 y 2007) y Choque (2009).

28 Acerca de la redistribución de la población aymara en la región durante el siglo XX, la inserción urbana y su economía contemporánea son importantes los trabajos de González (1996a y b, 1997a y b).

29 "Aquí en Arica hay bastantes bolivianos. Generalmente se desempeñan en la agricultura, generalmente en Azapa. Nosotros desempeñamos trabajos como, por ejemplo, comerciantes, panificadores y también tengo colegas sastres, yo soy sastre. Yo diría que el $85 \%$ de los bolivianos residentes trabajan en agricultura y hemos tenido una buena acogida de los dueños de parcelas en Azapa, no son grandes parceleros, 20 hectáreas, 30 hectáreas, Azapa no es un valle muy extenso" (aymara, hombre adulto, urbano).

30 Y tampoco de enclaves étnicos dado que, quizá con la excepción de Arica, no se reúnen las condiciones económicas y sociales para su conformación: porcentajes relativamente importantes de residentes étnicos en áreas urbanas definidas, una economía étnica diferenciable que los aglutina y profusas redes sociales correspondientes a esa residencia y economía (véase Portes y Jensen 1987:768-771). Para una opinión en contrario referida a los mapuches de Santiago, consúltese Rasse y Sabatini (2013:183-209).

31 "Antes el niño aymara se quedaba callado, el niño de origen andino se quedaba callado, pero hoy día se defiende, se defiende [más]" (no aymara, mujer adulta, urbana). 
